Pontifícia Universidade Católica do Rio de Janeiro

\title{
As práticas de Gestão de Pessoas mais valorizadas pela Geração Y
}

Manuela Jesus

Trabalho de Conclusão de Curso

Centro de Ciências Socials - CCS

DEPARTAMENTO DE ADMINISTRAÇÃO

Graduação em Administração de Empresas 


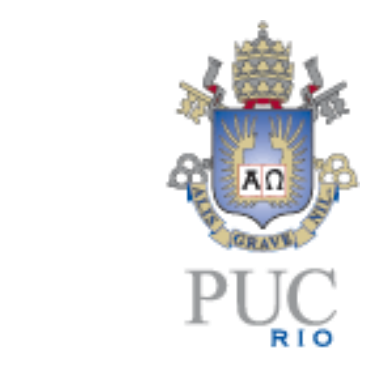

Manuela Jesus

\section{As práticas de Gestão de Pessoas mais valorizadas pela Geração Y}

Trabalho de Conclusão de Curso

Trabalho de Conclusão de Curso, apresentado ao programa de graduação em Administração da PUC-Rio como requisito parcial para a obtenção do título de graduação em Administração.

Orientador(a) : Patricia Itala Ferreira

Rio de Janeiro

Novembro de 2015. 


\section{Agradecimentos}

Agradeço primeiramente a Deus por tudo, por estar sempre ao meu lado e não desistir de mim.

Agradeço ao meu pai (in memoriam), meu maior amor, meu maior incentivador e meu melhor amigo. Sem a sua ajuda eu não estaria me formando. Para você e por você sempre.

À minha mãe, minha sobrinha, meus irmãos e minha família, por todo apoio e por serem minha fortaleza.

Aos meus amigos por toda ajuda, pelo carinho e por estarem comigo sempre.

A todos os meus professores da PUC-Rio pela formação, pelos conhecimentos e pelo aprendizado e, em especial, a minha orientadora, Patricia Itala Ferreira, pela dedicação e paciência que foram a base para a conclusão desse trabalho. 


\section{Resumo}

Jesus, Manuela. As práticas de Gestão de Pessoas mais valorizadas pela Geração Y. Rio de Janeiro, 2015. 55 p. Trabalho de Conclusão de Curso Departamento de Administração. Pontifícia Universidade Católica do Rio de Janeiro.

Uma nova geração de jovens começa a disputar seu espaço com gerações anteriores no mercado de trabalho. Essa geração possui características e motivações peculiares e está exigindo mudanças no ambiente organizacional, fazendo com que os profissionais da área de Gestão de Pessoas busquem entendê-la para que obtenham sucesso na atração e retenção desses jovens profissionais. O presente trabalho tem como objetivo identificar as práticas de Gestão de Pessoas mais valorizadas pela Geração Y e, para isso, foi realizada uma pesquisa de campo com uma amostra composta por alunos de Administração da PUC-Rio, formandos de Dezembro de 2015 e Junho de 2016, e que já tenham vivenciado alguma experiência de trabalho e/ou estágio no ambiente organizacional.

Palavras-chave: Geração Y; Gestão de Pessoas; ambiente organizacional.

\section{Abstract}

Jesus, Manuela. The practices of People Management most valued by Generation Y. Rio de Janeiro, 2015. 55 p. Trabalho de Conclusão de Curso - Departamento de Administração. Pontifícia Universidade Católica do Rio de Janeiro.

A new generation of young people begins to dispute their space with previous generations in the job market. This generation has unique characteristics and motivations, and is demanding changes in the organizational environment. They are forcing the People Management professionals to understand them to obtain success of attracting and retaining these young professionals. The present study aims to identify the People Management practices most valued by Generation $Y$ and, for that, a survey was held with a sample of Business students of PUC-Rio, classes of December 2015 and June 2016, which already have had work/internship experience in the organizational environment.

Key-words: Generation Y; People Management; organizational environment. 


\section{Sumário}

1 O tema e o problema de estudo 1

1.1. Introdução ao tema e ao problema do estudo 1

1.2. Objetivo do estudo 2

1.3. Objetivos intermediários do estudo 2

1.4. Delimitação e foco do estudo 2

1.5. Justificativa e relevância do estudo 2

2 Revisão de literatura 4

2.1. Gerações 4

2.1.1. A Geração $Y$

2.1.1.1. Expectativas e Motivações da Geração Y 7

2.1.1.2. Geração Y e o Mercado de Trabalho 9

2.2. Gestão de Pessoas 10

2.3. Treinamento, Desenvolvimento e Carreiras 13

$\begin{array}{ll}\text { 2.3.1. Treinamento e Desenvolvimento } & 13\end{array}$

$\begin{array}{ll}\text { 2.3.2. Carreiras } & 17\end{array}$

2.3.2.1. Carreiras Organizacionais 18

$\begin{array}{ll}\text { 2.3.2.2. Carreiras Sem Fronteiras } & 19\end{array}$

2.3.2.3. Carreiras Proteanas 21

2.4. Ambiente Organizacional 22

2.4.1. Clima Organizacional 22

2.4.2. Qualidade de Vida no Trabalho 24

3 Métodos e procedimentos de coleta e de análise de dados do estudo 27

3.1. Etapas, Procedimentos e Instrumentos de coleta de dados 27

3.2. Limitações do Estudo 28

4 Apresentação e análise dos resultados 30

4.1. Descrições dos resultados 30

4.1.1. Descrição do perfil dos respondentes 30 
5 Conclusões e recomendações para novos estudos

5.1. Conclusão 39

5.2. Sugestões e recomendações para novos estudos 41

6 Referências Bibliográficas 43

Apêndice 1

\section{Lista de figuras}

Figura 1: Os seis processos de Gestão de Pessoas .......................................... 13

Figura 2: Técnicas de treinamento ................................................................. 15

\section{Lista de Tabelas}

Tabela 1: Ética profissional tradicional x Ética profissional da geração $Y$............. 8

Tabela 2: Eras da história, seus respectivos anos e valores ............................. 11

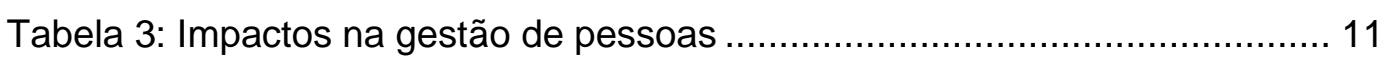

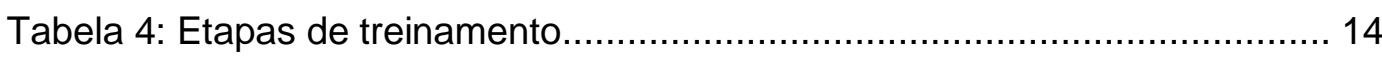

Tabela 5: Tendências da transformação das carreiras sem fronteiras................ 20

Tabela 6: Características da carreira proteana.................................................. 21

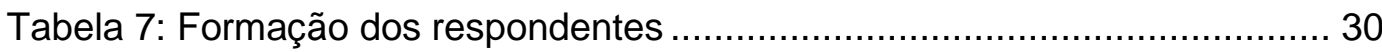

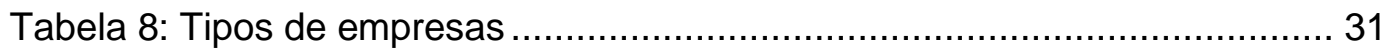

Tabela 9: Atividades realizadas atualmente pelos respondentes........................ 31

Tabela 10: Motivos de saída da empresa dos respondentes que não trabalham e

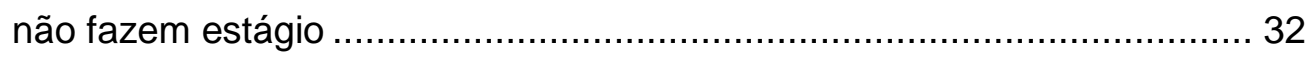

Tabela 11: Motivos dos respondentes que trabalham ou fazem estágio para saírem da atual empresa. 32 
Tabela 12: Respostas das afirmações sobre treinamento e desenvolvimento ... 34

Tabela 13: Respostas das afirmações sobre carreiras organizacionais............. 34

Tabela 14: Respostas das afirmações sobre carreiras sem fronteiras............... 35

Tabela 15: Respostas das afirmações sobre carreiras proteanas .................... 36

Tabela 16: Respostas das afirmações sobre clima organizacional .................... 36

Tabela 17: Respostas das afirmações sobre qualidade de vida no trabalho ..... 37

Tabela 18: Práticas de Gestão de Pessoas em ordem de importância.............. 38

Tabela 19: Respostas positivas e negativas do Bloco II do questionário ........... 39

Tabela 20: Práticas de Gestão de Pessoas em ordem de classificação ............ 40 


\section{0 tema e o problema de estudo}

\subsection{Introdução ao tema e ao problema do estudo}

O cenário atual em que as organizações estão inseridas revela uma grande complexidade e competitividade. Segundo Mósca, Cereja e Bastos (2014), o ambiente de negócios contemporâneo é dinâmico e marcado por transformações que aumentam essa complexidade, como a globalização e a evolução tecnológica.

Para esses autores, esse ambiente proporciona grandes desafios para a área de Gestão de Pessoas, que precisa estar atenta a como esse dinamismo e complexidade impactam em suas atividades.

Nesse contexto, torna-se relevante considerar o conceito de gerações e seu impacto no ambiente organizacional. A Geração $Y$, que corresponde aos nascidos entre 1980 e 2000 (LIPKIN E PERRYMORE, 2010), começa a entrar no mercado de trabalho, onde já existem membros de outras gerações com características e expectativas diferentes. Segundo Oliveira (2010), essa geração é individualista, necessita constantemente de feedbacks e consegue se expressar no estilo de vida, na linguagem que adota e no modo que usam as roupas. Os jovens dessa geração importam-se mais com a conexão e os relacionamentos com as pessoas, exigem respostas claras e diretas, assim como transparência, e possuem mais habilidades em absorver informações do que as gerações anteriores.

As expectativas e motivações dessa geração precisam ser analisadas para que a área de Gestão de Pessoas possa gerenciá-las e lidar com suas individualidades, interesses e aspirações, pois, segundo Oliveira (2010), a Geração $Y$ reage de forma diferente aos estilos de liderança dos gestores no ambiente organizacional, forçando-os a agirem como líderes de pessoas (SANTOS, 2011).

Para entender melhor essas expectativas da Geração Y sobre as práticas de Gestão de Pessoas, coloca-se a seguinte questão para o estudo: Quais são as práticas de Gestão de Pessoas mais valorizadas pela Geração Y? 


\subsection{Objetivo do estudo}

O presente estudo tem como objetivo identificar as práticas de Gestão de Pessoas mais valorizadas pela Geração $\mathrm{Y}$, verificando sua relação com as características sobre essa geração apresentada na revisão da literatura.

\subsection{Objetivos intermediários do estudo}

Para atingir o objetivo final estabelecido para esse estudo, alguns objetivos intermediários foram traçados:

- Apresentar e analisar a Geração Y, assim como seus anseios e motivações;

- Entender como essa geração se comporta no ambiente organizacional;

- Apresentar a área de Gestão de Pessoas e definir suas práticas de treinamento e desenvolvimento, carreiras, clima organizacional e qualidade de vida no trabalho;

\subsection{Delimitação e foco do estudo}

O estudo delimita-se a identificar as práticas de Gestão de Pessoas mais valorizadas pela Geração Y, abordando treinamento e desenvolvimento, carreiras, clima organizacional e qualidade de vida no trabalho, pois estão mais relacionados às características apresentadas na literatura sobre a Geração Y.

Trata-se de um estudo restrito aos alunos do curso de Administração da PUC-Rio, formandos do final de 2015 e do meio de 2016, e integrantes da Geração Y.

\subsection{Justificativa e relevância do estudo}

No ambiente competitivo atual, conhecer o que motiva seus funcionários é um fator chave para as organizações. O presente estudo é relevante porque visa identificar práticas de Gestão de Pessoas mais valorizadas pela Geração Y, apresentando características peculiares dessa geração que podem ser usadas pela área de Gestão de Pessoas a favor das organizações com o objetivo de atrair e reter os jovens dessa geração, assim como traçar novas políticas que proporcionem desenvolvimento para esses jovens, considerando suas características e motivações. 
Apresentar os anseios e motivações desses jovens no ambiente de trabalho também contribui para o melhor entendimento de seus gestores, os quais precisam saber exatamente o que motiva essa geração para possam buscar o melhor desempenho profissional dela.

Para os integrantes da Geração Y, o presente estudo é relevante ao relacionar as práticas de Gestão de Pessoas às motivações e anseios dessa geração, sendo útil na identificação de organizações que valorizem esses aspectos, usando essas práticas para desenvolver os profissionais dessa geração.

O trabalho também é relevante aos professores e alunos de Administração para o melhor entendimento dos jovens da Geração $Y$ no ambiente organizacional, podendo ser aproveitado para complementar outros estudos que utilizam essa geração e o ambiente de trabalho como tema. 


\section{Revisão de literatura}

\subsection{Gerações}

O conceito de gerações está relacionado a um grupo de pessoas nascido em uma mesma época, sendo influenciado por um contexto histórico, o que determina comportamentos e impacta diretamente na evolução da sociedade (KULLOCK, 2010). Este conceito aceito e reconhecido pela sociedade moderna considera vinte anos como marco que separa uma geração de outra (OLIVEIRA, 2010).

De acordo com Lipkin e Perrymore (2010) cada geração considera a sua a única, a mais avançada, mais original e competente do que as gerações antecessoras, porém, para essas autoras, cada geração influencia a seguinte, que essa influencia a outra e assim por diante. Para Oliveira (2010) é preciso conhecer as características das gerações anteriores, pois elas interferem no futuro da sociedade. Além disso, para esse autor, os pais de gerações anteriores também influenciam as características das gerações futuras, pois eles educam seus filhos de modo a não sofrerem as mesmas dificuldades enfrentadas por eles.

Segundo o autor, a geração nascida entre 1920 e 1940 foi afetada diretamente pela Segunda Guerra Mundial. Mesmo sendo abalada pela guerra com suas crises e catástrofes, essa geração desenvolveu fortes valores de compaixão e solidariedade, e foi motivada pelo desejo de reconstruir a sociedade da época. Considerava que só alcançaria isso com dedicação e muito trabalho, e sabia que o dever sempre viria antes do prazer. Essa geração foi marcada pela disciplina, honra, respeito e organização, que definiam o comportamento na sociedade da época.

O período de pós-guerra (1945-1960), conhecido como "Anos Dourados", deu início a uma nova geração de jovens, os chamados Baby Boomers. Seus pais estavam reconstruindo a sociedade e educaram essa geração com um conceito de disciplina rígida. Os jovens aprenderam desde cedo a respeitar os valores familiares e a ter disciplina nos estudos, o que também fazia serem 
aceitos nos grupos existentes na sociedade. Contudo, os comportamentos estabelecidos pelos pais e pela sociedade da época criaram uma situação insustentável, levando esses jovens ao refúgio artístico, onde a música representava as insatisfações com a realidade em que viviam. Nessa época, surgiram nomes como Elvis Presley, Jerry Lee Lewis, Bob Dylan, Beatles e Rolling Stones (OLIVEIRA, 2010).

\begin{abstract}
Os "Anos Dourados", com toda rigidez e disciplina, foram o principal motivo para o surgimento de jovens mais rebeldes e contestadores cujo desenvolvimento foi marcado por escolhas que transgredissem todas as regras, toda ordem que estivesse estabelecida. Comportamentos como fumar, fazer sexo fora do casamento, usar cabelos compridos e roupas justas eram manifestações facilmente vistas nas ruas (OLIVEIRA, 2010, p.51).
\end{abstract}

Entre os anos de 1960 e 1980, a geração Baby Boomers chegou à vida adulta e esse período ficou marcado por diversas rebeliões contra o governo. Surgiram os movimentos hippies, rebeliões dos estudantes e também foi nessa época que emergiu a Geração X. As características dos jovens dessa geração foram moldadas pela criação da TV e sua programação determinava rotinas e comportamentos, além de ser usada como moeda de troca na educação desses jovens, ou seja, se eles tivessem boas notas e bom comportamento, poderiam assistir a TV (OLIVEIRA, 2010).

De acordo com o autor, diferentemente da Geração Baby Boomers, a Geração X não se identificou com a agressividade proposta pelos movimentos revolucionários vividos por seus pais e adotou uma posição omissa, evitando manifestações sociais. Porém, alguns pais Baby Boomers conseguiram transmitir alguns valores e conceitos que aprenderam para seus filhos, desencadeando a busca pela estabilidade financeira e construção de uma família exemplar, mesmo que para eles o divórcio de seus pais já fosse algo normal.

Atualmente, é possível encontrar algumas gerações trabalhando juntas no ambiente empresarial. A mais nova entrante nesse meio é a Geração $Y$ ou Geração Millennials nascida entre os anos de 1980 e 2000 (LIPKIN E PERRYMORE, 2010). 


\subsubsection{A Geração $Y$}

Segundo Lipkin e Perrymore (2010), a Geração Y foi mais desejada como nenhuma outra anterior foi. Ela foi fortemente influenciada pela tecnologia, e presenciou vários avanços, como a criação e difusão da internet (MÓSCA, CEREJA E BASTOS, 2014), o que proporcionou ao jovem dessa geração ter "sua fome de conhecimento recompensada" (OLIVEIRA, 2010, p.46). De acordo com esse autor, diferentemente da TV que marcou a Geração X, para a Geração Y a internet foi um marco, tornando o mundo muito "menor" para ela. Para Lipkin e Perrymore (2010), a tecnologia é um estilo de vida para os jovens dessa geração, influenciando seus valores, princípios e comportamentos.

Oliveira (2010) afirma que os jovens dessa geração nasceram de famílias, onde o convívio com os pais é diferente do que acontecia nas outras gerações. De acordo com Lipkin e Perrymore (2010), os pais (Gerações X e Baby Boomers) desses jovens adotaram uma postura de educação focada nos filhos:

\footnotetext{
Os pais da Geração $\mathrm{Y}$ procuraram se concentrar em desenvolver um bom relacionamento com seus filhos, dandoIhes apoio, força e proteção incondicional, além de proporcionar os meios para que eles crescessem e se expressassem livremente (LIPKIN E PERRYMORE, 2010, p.2).
}

Ainda segundo essas autoras, os jovens dessa geração foram criados com a frase você pode ser o que quiser, foram recompensados, independe do merecimento, e seus pais e a sociedade os ensinaram a não temerem o fracasso, o que elevou a autoestima dessa geração e gerou jovens conscientes de seus pontos fortes, que não querem assumir os seus erros ou pontos fracos e não conseguem aceitar críticas construtivas. Para Oliveira (2010), houve um empenho muito forte dos pais com os filhos em proporcionar as melhores escolas, o melhor curso de línguas e as melhores atividades para o desenvolvimento desses jovens.

Segundo esse autor, a Geração $Y$ necessita constantemente de reconhecimento, pois aprendeu a receber feedbacks de todas as suas ações desde a infância. Isso gerou jovens impacientes e que desejam saber a todo o momento a avaliação das pessoas em relação às suas ações. Além disso, essa geração busca adquirir novos conhecimentos como, por exemplo, outros cursos de línguas ao invés do Inglês, porque já possui intimidade com este idioma nos jogos de videogames, nos filmes e nas músicas. Oliveira (2010) também afirma 
que o foco na realização profissional existente nas gerações de seus pais, fez com que eles tivessem menos filhos e buscassem condições financeiras mais favoráveis, o que, consequentemente, aumentou a individualidade dos jovens da Geração $Y$ que passaram a ter seus próprios quartos, suas próprias televisões, seus videogames, telefone, computador e internet.

De acordo com esse autor, essa geração questiona com frequência, é ansiosa e impaciente em quase todas as situações, desenvolve ideias e pensamentos superficiais, busca viver intensamente cada experiência e é ambígua em suas decisões e escolhas. É uma geração talentosa, socialmente consciente, que exige muito e é criativa (LIPKIN E PERRYMORE, 2010).

\title{
2.1.1.1. Expectativas e Motivações da Geração $Y$
}

Motivação é uma força intrínseca que impulsiona uma pessoa na direção de algo. Ela nasce das necessidades internas de uma pessoa e, por isso, somente essa consegue se motivar. As pessoas de fora conseguem apenas incentivar e provocar a motivação (VERGARA, 1999).

Para Lipkin e Perrymore (2010), existem dois tipos de motivação: externa (extrínseca) e interna (intrínseca). A primeira está relacionada à uma recompensa como reconhecimento ou medo de punição. No ambiente de trabalho se um indivíduo não receber recompensa constante, como consequência, pode ficar frustrado e diminuir sua produtividade. Já a motivação interna é aquela relacionada ao entusiasmo. Nesse caso, as recompensas externas são aceitas, mas não são prioridades.

De acordo com essas autoras, os jovens da Geração Y não sabem o que realmente os motivam por falta de autoconhecimento:

\begin{abstract}
[...] existe um consenso geral entre os jovens dessa geração de que eles estão predestinados a ter sucesso. Isso aconteceu porque, até começar a trabalhar, esses jovens sempre receberam recompensas e elogios por seu desempenho, independentemente dos resultados, passando a acreditar, portanto, que até mesmo pequenos esforços e resultados insatisfatórios valem. Eles acham que estão sendo motivados por seus próprios padrões internos. Ledo engano, que reflete a falta de autoconhecimento quanto a suas necessidades motivacionais (LIPKIN E PERRYMORE, 2010, p.70).
\end{abstract}

Segundo Oliveira (2010), os jovens da Geração Y possuem como motivação pessoal outros fatores além da remuneração, como era no passado para outras gerações. Um dos fatores é o bom relacionamento com o líder que 
impacta em sua dedicação às atividades. Se há uma relação boa, os jovens da Geração $Y$ criam uma ligação profunda e tentam mostrar que merecem o aprendizado, mas caso a relação seja ruim, eles desenvolvem uma atitude negativa em relação ao líder. Esses jovens são motivados por desafios que acarretam em seu crescimento profissional e importam-se com o ambiente de trabalho. Para Sá, Lemos e Cavazotte (2014), eles desejam um ambiente de trabalho agradável e relacionam prazer e satisfação à condução do trabalho, assim como buscam manter um equilíbrio entre vida profissional e pessoal (SANTOS, 2011).

Os cargos de liderança ocupados pelas gerações Baby Boomers e X definiram uma ética profissional que é vista até hoje no ambiente corporativo. Contudo, a Geração $Y$ está exigindo mudanças nesse cenário para que ele possa refletir seus valores e o seu modo de se relacionar com o trabalho (LIPKIN E PERRYMORE, 2010).

Tabela 1: Ética profissional tradicional $x$ Ética profissional da geração $Y$

\begin{tabular}{|c|c|}
\hline Ética profissional tradicional & Ética profissional da Geração Y \\
\hline O trabalho em primeiro lugar. & A vida em primeiro lugar. \\
\hline $\begin{array}{l}\text { Distinção entre horário de trabalho e } \\
\text { horário de lazer. }\end{array}$ & $\begin{array}{l}\text { Indistinção entre horário de trabalho e } \\
\text { horário de lazer = integração vida } \\
\text { profissional/vida pessoal. }\end{array}$ \\
\hline Segue regras acima de tudo. & $\begin{array}{l}\text { Segue regras que funcionam e } \\
\text { estabelece as próprias regras. }\end{array}$ \\
\hline O chefe merece respeito. & Respeito só quando merecido. \\
\hline Tempo de serviço = promoção. & Talento = promoção. \\
\hline $\begin{array}{l}\text { Expediente das } 9 \mathrm{~h} \text { às } 18 \mathrm{~h} \text {, com horas } \\
\text { extras. }\end{array}$ & Horário de trabalho indefinido. \\
\hline Trabalho baseado em horas. & $\begin{array}{l}\text { Quando terminar o trabalho, posso ir } \\
\text { embora, mesmo que seja antes das } \\
\text { seis. }\end{array}$ \\
\hline Preferência por contato pessoal. & Preferência por contato virtual. \\
\hline Veste sempre a camisa. & Veste a camisa quando necessário. \\
\hline $\begin{array}{l}\text { Muda de acordo com as necessidades } \\
\text { da empresa. }\end{array}$ & $\begin{array}{l}\text { Espera que a empresa mude de } \\
\text { acordo com suas necessidades. }\end{array}$ \\
\hline
\end{tabular}

Fonte: Lipkin e Perrymore (2010, p.127)

As práticas empresariais formais estão sendo questionadas pela Geração $Y$, forçando o ambiente de trabalho a aceitar sua ética. Dessa forma, os jovens profissionais dessa geração "querem ser reconhecidos pelo que têm a oferecer e, ao mesmo tempo, ser respeitados por sua plenitude e filosofia de que o trabalho faz parte da vida, mas não é a vida" (LIPKIN E PERRYMORE, 2010, p.126). 


\subsubsection{Geração Y e o Mercado de Trabalho}

Segundo Oliveira (2010), a Geração Y está chegando agora ao ambiente de trabalho e começa a influenciar de forma direta a sociedade. De acordo com esse autor, a figura do pai fora de casa já era comum nas gerações anteriores, contudo, para a Geração $Y$ as mães também foram em busca de autonomia e realização profissional. Por isso, os jovens dessa geração chegam ao mercado de trabalho com uma qualificação mais elevada devido aos pais compensarem suas ausências - enquanto estavam trabalhando - oferecendo a melhor educação com o objetivo desses jovens se tornarem mais competitivos no futuro.

Isso também é evidenciado por Santos (2011), que relata que esses jovens chegam preparados para novos desafios e entrega de resultados no ambiente de trabalho, devido à preparação que seus pais impuseram. Contudo, as qualificações e as informações adquiridas através da tecnologia podem gerar profissionais arrogantes que se consideram essenciais para uma organização.

Para Lipkin e Perrymore (2010), a influência na educação desses jovens fez com que eles se tornassem mais autocentrados, assumissem menos responsabilidades e possuíssem expectativas menos realistas, o que causa grande impacto no ambiente de trabalho. Além disso, essa superproteção dos pais tornou essa geração incapaz de encarar os fracassos, menos responsável e menos independente no trabalho, o que gera desconforto nos chefes porque eles querem que esses jovens desenvolvam suas habilidades e sejam independentes.

Os pais desses jovens possuem altas expectativas em ver os resultados dos investimentos nos filhos. Mas no ambiente empresarial, os gestores possuem pouca disposição em aceitar os comportamentos deles, o que impacta no desenvolvimento desses jovens (OLIVEIRA, 2010).

De acordo com esse autor, a Geração $Y$ está habituada com as mudanças e não tem expectativas duradouras quanto às gerações passadas. Ao contrário de seus pais, esses jovens possuem projetos de vida de curto prazo e rápidos, e também eles buscam felicidade agora, não querem esperar para depois.

Para Sá, Lemos e Cavazotte (2014, p.25), esta geração constitui uma:

[...] força de trabalho que: deseja fazer carreira, desde que esta seja bem rápida; obter reconhecimento simbólico e material, ao mesmo tempo em que anseia por qualidade de vida; e valoriza a autonomia sem abrir mão da segurança. 
Os jovens da Geração $Y$ têm necessidade de saberem como estão dentro da empresa com frequência e querem saber se conseguem crescer, "pois caso contrário irão 'abandonar o jogo' e partir para outro desafio” (OLIVEIRA, 2010, p.130). Para Santos (2011), eles vão em busca de oportunidades que the são mais adaptadas. Ao contrário da Geração X que fica durante vários anos em uma mesma empresa, a Geração $Y$ dificilmente permanece mais de dois anos na mesma posição (MÓSCA, CEREJA E BASTOS, 2014).

Segundo Oliveira (2010), os modelos de gestão do século passado estão perdendo a eficácia por causa do surgimento das novas gerações no ambiente empresarial, as quais reagem de forma diferente aos estilos de liderança adotados pelos gestores atuais.

Santos (2011) propõe que a empresa precisa ter um plano de desenvolvimento desses jovens profissionais para orientá-los e também auxiliar seus gestores. Além disso, para esse autor, quanto menor for o apoio oferecido pela área de Gestão de Pessoas, haverá muita dificuldade em gerenciar os jovens da Geração $Y$, pois ela está forçando os gestores a agirem como líderes de pessoas. Oliveira (2010) destaca que os gestores devem estimular o aprendizado desses jovens e não criar bloqueios, controles ou limites.

\subsection{Gestão de Pessoas}

Segundo Mósca, Cereja e Bastos (2014), o conceito de Gestão de Pessoas corresponde a um conjunto de ações de uma pessoa ou de um grupo de pessoas, dentro das organizações, auxiliando o trabalho individual e coletivo visando os objetivos e metas organizacionais.

As pessoas tornaram-se o capital intelectual das empresas e passaram a ser consideradas parceiras. Cada parceiro investe seus recursos numa organização e conforme ela cresce, é preciso valorizar o funcionário, já que ele é um dos parceiros mais importante (GIL, 2001). Para Chiavenato (2010), as empresas passaram a considerar seus funcionários o seu ativo mais importante e não apenas como recursos.

De acordo com Oliveira (2010), o valor de uma pessoa mudou muito rápido ao longo da história humana, o que ele dividiu em eras. Na Era da Agricultura (até 1776) o valor atribuído ao ser humano era associado à posse da terra, ou seja, quem possuísse terra era relevante perante os demais na sociedade. Na Era do Artesanato (até 1860), o valor da pessoa estava associado 
à sua força de trabalho, valor este que transitou para a posse de capital na Era Industrial (até 1970) devido às transformações na sociedade, as novas tecnologias e invenções, assim como o surgimento de novos modelos de organizações e de trabalho. Contudo, a velocidade das transações comerciais internacionais e o rápido crescimento populacional acarretaram em grandes avanços tecnológicos que a informação (o conhecimento) tornou-se o principal valor que uma pessoa poderia ter. Assim, até o ano de 2000, a Era do Conhecimento predominou.

Tabela 2: Eras da história, seus respectivos anos e valores

\begin{tabular}{|c|c|c|}
\hline ERAS & ATÉ O ANO DE & PRINCIPAL VALOR \\
\hline Agricultura & 1776 & Terra \\
\hline Artesanato & 1860 & Trabalho \\
\hline Industrial & 1970 & Capital \\
\hline Conhecimento & 2000 & Informação \\
\hline
\end{tabular}

Fonte: Oliveira (2010, p.25)

Segundo Vergara (1999), na sociedade da informação o valor transitou dos músculos para a mente, onde o conhecimento passou a ser o primeiro recurso e a terra, o trabalho braçal e o capital assumiram um papel secundário. A informação ultrapassa fronteiras geográficas e dissemina o processo de globalização, aumentando a complexidade e acirrando a competitividade. Para Chiavenato (2010), o capital financeiro foi substituído pelo conhecimento na Era da Informação, e com a globalização do mundo dos negócios, o antigo modelo presente nas organizações não funciona mais. Para Gil (2001), isso exige que as organizações desenvolvam seus funcionários para que elas possam crescer globalmente ao mesmo tempo em que promovem as condições locais.

A complexidade do ambiente corporativo impacta diretamente as organizações e mostram que a área de gestão de pessoas tem muitos desafios (MÓSCA, CEREJA E BASTOS, 2013). O quadro a seguir apresenta esses impactos na gestão de pessoas.

Tabela 3: Impactos na gestão de pessoas

\begin{tabular}{|l|l|}
\hline \multicolumn{1}{|c|}{ Passado } & \multicolumn{1}{c|}{ Hoje } \\
\hline Visão funcional & Visão holística \\
\hline Conhecimento fragmentado & Conhecimento integrado \\
\hline Hierarquia & Adhocracia \\
\hline Controle de recursos & Mobilidade de recursos \\
\hline
\end{tabular}




\begin{tabular}{|l|l|}
\hline \multicolumn{1}{|c|}{ Passado } & \multicolumn{1}{c|}{ Hoje } \\
\hline Autossuficiência & Colaboração \\
\hline Desenvolvimento & Sustentabilidade \\
\hline Competências estáveis & Competências dinâmicas \\
\hline $\begin{array}{l}\text { Esferas social e profissional bem profissional } \\
\text { definidas }\end{array}$ & $\begin{array}{l}\text { Esferas social e } \\
\text { conectadas }\end{array}$ \\
\hline Imobilidade social & Mobilidade social \\
\hline Gestão técnico-funcional & Gestão humanista \\
\hline Gestão de recursos humanos & Gestão estratégica de pessoas \\
\hline \multicolumn{1}{|c|}{ Eficiência e eficácia } & \multicolumn{1}{|c|}{ Efetividade } \\
\hline \multicolumn{2}{|c|}{} \\
\hline
\end{tabular}

Fonte: Mósca, Cereja e Bastos (2014, p.27)

Nesse contexto, segundo Mósca, Cereja e Bastos (2014, p.1), o conhecimento das pessoas deve ser valorizado pelas organizações:

O conhecimento - mais do que terra, capital ou trabalho - vem se tornando o fator-chave da produção e da geração de riqueza. E como conhecimento está nas pessoas, é delas que a organização precisa saber cuidar. É assim que se situa hoje, nesse cenário, a gestão de pessoas.

Para esses autores, as organizações precisam elaborar mapas de carreira, avaliações de desempenho e alternativas diferentes de remuneração para que as pessoas sejam recompensadas de acordo com suas contribuições para o negócio e também para que elas fiquem na organização.

De acordo com Chiavenato (2010), os propósitos da Gestão de Pessoas envolvem o alcance dos objetivos e realização da missão da organização, além de proporcionar competitividade e pessoas bem treinadas e motivadas. Para esse autor, existem seis processos da nova gestão de pessoas, os quais são apresentados na figura 1 .

Os processos de agregar pessoas são relacionados à inclusão de novas pessoas na organização; os processos de aplicar pessoas são usados para desenhar as atividades que as pessoas irão desempenhar na empresa, orientando-as e acompanhando-as; os processos de recompensar pessoas são usados com incentivos para as pessoas satisfazerem suas necessidades individuais mais altas; os processos de desenvolver pessoas são utilizados para alavancar o desenvolvimento profissional e pessoal das pessoas; os processos de manter pessoas estão relacionados à criação de melhores condições para o desempenho das atividades das pessoas; e os processos de monitorar pessoas estão relacionados ao acompanhamento das atividades dessas pessoas (CHIAVENATO, 2010). 
Figura 1: Os seis processos de Gestão de Pessoas

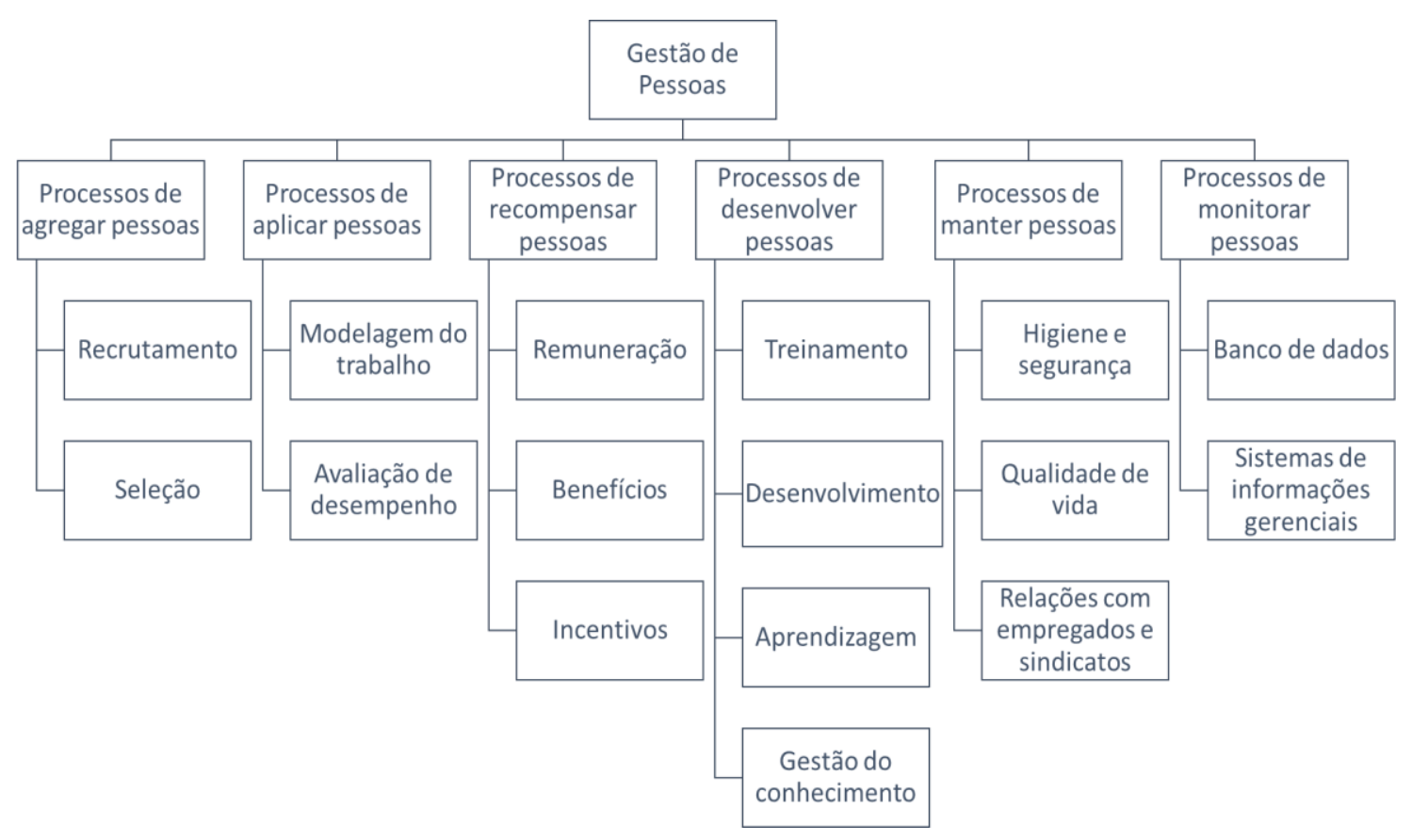

Fonte: Chiavenato $(2010$, p.15)

Ainda segundo o autor, todos esses processos estão ligados e influenciam um ao outro. Quando bem ou mal utilizados podem impactar favorecendo ou prejudicando os demais. É necessário que haja equilíbrio na execução de todos esses processos.

Para fins de trabalho, serão conceituadas algumas práticas pertencentes aos processos de desenvolver, recompensar e manter pessoas da área de Gestão de Pessoas, como treinamento e desenvolvimento, carreiras, clima organizacional e qualidade de vida no trabalho porque estão mais relacionados às características apresentadas na literatura como anseios da Geração Y, a qual é motivada por desafios que proporcionem seu desenvolvimento profissional (OLIVEIRA, 2010), e tem o objetivo de fazer carreira de forma rápida, ao mesmo tempo em que anseia por qualidade de vida e preocupa-se com um ambiente de trabalho agradável (SÁ, LEMOS E CAVAZOTTE, 2014).

\subsection{Treinamento, Desenvolvimento e Carreiras}

\subsubsection{Treinamento e Desenvolvimento}

No atual cenário de mudanças constantes e competição, as organizações precisam se preparar para os crescentes desafios, e para obterem sucesso, elas 
precisam de pessoas capazes de fazer as coisas acontecerem. Para isso, é preciso investir em treinamentos e no desenvolvimento dessas pessoas, as quais constituem o principal patrimônio das empresas. $O$ treinamento deve ser visto como investimento e não como despesa organizacional (CHIAVENATO, 2010).

Para Gil (2001), treinamento corresponde às experiências de aprendizagem de curto prazo na posição atual da empresa. Envolve ações com o objetivo de ampliar a capacidade das pessoas no melhor desempenho das funções no cargo que ocupam dentro da organização.

Ainda segundo esse autor, o desenvolvimento está relacionado às experiências de aprendizagem de longo prazo, podendo ser nos cargos que as pessoas ocupam no momento ou que ocuparão no futuro, e proporciona oportunidades de crescimento e desenvolvimento profissional. As ações de desenvolvimento de pessoas envolvem um compromisso maior da organização com suas capacitações.

Dessa forma, treinamento e desenvolvimento são "processos voltados à aprendizagem, que significa mudança no comportamento das pessoas, por meio da incorporação de novos conhecimentos, habilidades e atitudes" (GIL, 2001, p.123).

Para Chiavenato (2010), o capital humano deve ser bem desenvolvido pelas organizações. Para isso, o treinamento representa uma fonte de lucratividade porque aumenta esse capital. Ele constitui um processo composto por quatro etapas:

Tabela 4: Etapas de treinamento

\begin{tabular}{|c|l|}
\hline Diagnóstico & $\begin{array}{l}\text { É o levantamento das necessidades ou carências de } \\
\text { treinamento a serem atendidas ou satisfeitas. Essas } \\
\text { necessidades podem ser passadas, presentes ou futuras. }\end{array}$ \\
\hline Desenho & $\begin{array}{l}\dot{E} \text { a elaboração do projeto ou programa de treinamento para } \\
\text { atender às necessidades diagnosticadas. }\end{array}$ \\
\hline Implementação & $\dot{E}$ a execução e condução do programa de treinamento. \\
\hline Avaliação & $\hat{E}$ a verificação dos resultados obtidos com o treinamento. \\
\hline
\end{tabular}
Fonte: Próprio Autor (2015)

De acordo com Chiavenato (2010), na etapa de diagnóstico, o levantamento das necessidades de treinamento pode ser elaborado nos seguintes níveis: 
- Análise organizacional: verifica se o treinamento está atendendo à missão, visão e objetivos estratégicos a partir do diagnóstico de toda a empresa;

- Análise dos recursos humanos: determina quais os comportamentos, atitudes, conhecimentos e competências das pessoas são necessários para que elas possam ajudar no alcance dos objetivos estratégicos da organização a partir de uma análise do perfil dessas pessoas;

- Análise da estrutura de cargos: determina como as pessoas precisam ser desenvolvidas para desempenharem suas atividades através do exame dos requisitos e especificações dos cargos;

- Análise do treinamento: avalia a eficácia e eficiência do treinamento a partir dos objetivos e metas utilizados como critérios nessa avaliação.

Segundo esse autor, realizado o diagnóstico, segue-se para o desenho do programa de treinamento, sendo estabelecido quem deve ser treinado, como será o treinamento, quem treinará, onde será, quando ocorrerá e qual é o objetivo desse treinamento.

Figura 2: Técnicas de treinamento

\begin{tabular}{|c|c|c|c|}
\hline \multirow{7}{*}{$\begin{array}{l}\text { Técnicas de } \\
\text { treinamento }\end{array}$} & \multirow{3}{*}{$\begin{array}{l}\text { Quanto ao } \\
\text { uso }\end{array}$} & $\begin{array}{c}\text { Orientadas para o } \\
\text { conteúdo }\end{array}$ & $\begin{array}{l}\text { Leitura, instrução programada, } \\
\text { instrução assistida por computador }\end{array}$ \\
\hline & & $\begin{array}{l}\text { Orientadas para o } \\
\text { processo }\end{array}$ & $\begin{array}{c}\text { Dramatização, treinamento da } \\
\text { sensitividade, desenvolvimento de } \\
\text { grupos }\end{array}$ \\
\hline & & $\begin{array}{l}\text { Mistas (conteúdo e } \\
\text { processo) }\end{array}$ & $\begin{array}{c}\text { Estudo de casos, jogos e simulações, } \\
\text { conferências e várias técnicas on-the- } \\
\text { job }\end{array}$ \\
\hline & \multirow{2}{*}{$\begin{array}{l}\text { Quanto ao } \\
\text { tempo } \\
\text { (Época) }\end{array}$} & $\begin{array}{c}\text { Antes do ingresso na } \\
\text { empresa }\end{array}$ & $\begin{array}{c}\text { Programa de indução ou de integraçãc } \\
\text { à empresa }\end{array}$ \\
\hline & & $\begin{array}{c}\text { Após o ingresso na } \\
\text { empresa }\end{array}$ & $\begin{array}{l}\text { Treinamento no local (em serviço) ou } \\
\text { fora do local de trabalho (fora de } \\
\text { serviço) }\end{array}$ \\
\hline & \multirow{2}{*}{$\begin{array}{l}\text { Quanto ao } \\
\text { local }\end{array}$} & No local de trabalho & $\begin{array}{l}\text { Treinamento em tarefas, rodízio de } \\
\text { cargos, enriquecimento de cargos }\end{array}$ \\
\hline & & $\begin{array}{l}\text { Fora do local de } \\
\text { trabalho }\end{array}$ & $\begin{array}{c}\text { Aulas, filmes, painéis, casos, } \\
\text { dramatização, debates, simulações, } \\
\text { jogos }\end{array}$ \\
\hline
\end{tabular}

Fonte: Chiavenato (2010, p.380) 
Ainda segundo o autor, logo após o desenho, é feita a condução do programa de treinamento através de técnicas para transmitir a informação. Tais técnicas podem ser classificadas quanto ao uso, ao tempo e ao local, e representam a aplicação da teoria da aprendizagem, conforme figura 2. Posteriormente, é realizada avaliação do programa de treinamento.

O maior objetivo do treinamento é atingir o nível de desempenho desejado pela organização através de constante desenvolvimento dos funcionários. Para que o treinamento alcance o sucesso é necessário que a empresa tenha uma cultura que estimule o aprendizado e que tenha compromisso com as mudanças (CHIAVENATO, 2010).

Para esse autor, no contexto de ambiente em constantes mudanças, as organizações precisam ser rápidas e flexíveis, pois essas mudanças impactam no desenvolvimento das pessoas que nela trabalham. Existem métodos de desenvolvimento de pessoas dentro e fora do cargo em que ocupam numa empresa. Os principais métodos para desenvolver pessoas dentro do cargo atual são:

- Rotação de cargos: movimentação de uma pessoa em diversas posições dentro da empresa com o objetivo de expandir suas habilidades, conhecimentos e capacidades. Auxilia na transformação de especialistas em generalistas;

- Posições de assessoria: pessoa com alto potencial trabalha por um período sob a supervisão de um gerente de sucesso em diversas áreas da organização;

- Aprendizagem prática: consiste em um trabalho para analisar e resolver problemas em projetos que necessitam de cooperação ou em outros departamentos;

- Atribuição de comissões: pessoa participa de comissões de trabalho compartilhando da tomada de decisões, e aprendem a observar os outros e a pesquisar problemas da organização;

- Participação em cursos e seminários externos: constitui uma oportunidade de adquirir novos conhecimentos e desenvolver novas habilidades;

- Exercício de simulação: tem o objetivo de estimular as pessoas a resolverem problemas reais através de estudos de caso, jogos, entre outros; 
- Treinamento fora da empresa: constitui uma busca por novos conhecimentos, atitudes e comportamentos que não são encontrados dentro da organização, tornando-se necessário obter fora dela;

- Estudos de casos: técnica que ajuda a diagnosticar um problema real e tratar soluções, desenvolvendo habilidades de análise, comunicação e persuasão;

- Jogos de empresas: ajudam na tomada de decisão através de jogos com problemas reais ou simulados;

- Centros de desenvolvimento internos: constituem locais na empresa com o objetivo de melhorar habilidades pessoais através de exercícios;

- Coaching: o gerente pode desempenhar diversos papéis como líder para se transformar em um coach.

Métodos de desenvolvimento fora do cargo:

- Tutoria ou mentoring: desenvolvimento voltado para funcionários que desejam crescer na organização, recebendo assistência (mentoring) de executivos;

- Aconselhamento de funcionários: assemelha-se à tutoria, mas difere porque somente acontece quando surge um problema de desempenho de funcionário.

Para Mósca, Cereja e Bastos (2014), a maneira como as empresas conduzem seus planos de treinamento e desenvolvimento contribui de forma significativa para o clima organizacional. As práticas de treinamento e desenvolvimento estão relacionadas às competências pretendidas pela organização para a realização de sua estratégia.

Assim como treinamento e desenvolvimento são importantes para as empresas e para os funcionários, o crescimento profissional, ou seja, a carreira, também deve ser considerado.

\subsubsection{Carreiras}

Atualmente, as organizações estão inseridas em um contexto de pressão por flexibilidade, capacitando-as para agir e influenciar outras empresas. Ao mesmo tempo, as pessoas estão buscando atuar de forma independente no planejamento de suas carreiras (VELOSO, DUTRA E NAKATA, 2008). 
Segundo Martins (2010), o conceito de carreira passou a ser utilizado para definir a trajetória profissional de um indivíduo. No passado, ter uma carreira significava encontrar um emprego estável e de longo prazo, mas hoje não é exatamente assim. Para esse autor, a família, a sociedade e a cultura possuem forte influência na carreia de um profissional. Além do desejo de estabilidade, as pessoas passaram a buscar bem-estar no ambiente corporativo, realização pessoal, qualidade de vida e remuneração para alcançar seus objetivos pessoais (MÓSCA, CEREJA E BASTOS, 2014).

Carreira não tem o mesmo sentido que emprego. Nesse último, a organização é responsável por conceder os meios para o desenvolvimento e a gestão de carreira do empregado (MARTINS, 2010).

Ter um emprego estável e de longo prazo não é algo bom nem ruim - é uma opção pessoal de cada um. Uma carreira é algo diferente na medida em que implica o crescimento profissional e progressivo, se possível no curto prazo (MÓSCA, CEREJA E BASTOS, 2014, p.40).

As organizações conseguem alcançar o desenvolvimento de carreiras quando as outras práticas de Gestão de Pessoas interagem com o processo, como, por exemplo, treinamento e desenvolvimento e avaliação de desempenho (CHIAVENATO, 2010).

Contudo, para Veloso, Dutra e Nakata (2008), no contexto empresarial de hoje, as carreiras organizacionais não são predominantes como antes devido aos outros tipos de carreiras que surgiram. Para Dutra (2010), as pessoas tornaram-se responsáveis por suas próprias carreiras e devem assumir suas evoluções profissionais. Elas começam a pensar em suas carreiras de forma diferente, tendo cada vez menos a empresa como referência para suas decisões e usando cada vez mais elas mesmas e as oportunidades do mercado para seu posicionamento profissional e para construção de seu futuro.

Nesse contexto, contrapondo-se à concepção de carreiras organizacionais, surgem os conceitos de carreiras sem fronteiras e carreiras proteanas.

\subsubsection{Carreiras Organizacionais}

O conceito de carreiras organizacionais surgiu no ano de 1990 e estava ligado às grandes organizações, revelando um único cenário de emprego. Esse tipo de carreira foi moldada em um ambiente considerado estável e não 
dinâmico, onde há interdependência entre empresa e indivíduo. Sua estrutura é predeterminada pelas organizações e não é dirigida pelas pessoas, seguindo o conceito de que as grandes empresas podem oferecer carreiras para a vida toda de uma pessoa. A aprendizagem se dá mais internamente à organização que no ambiente externo (DUTRA, 2010). Para Chiavenato (2010), antigamente as empresas elaboravam um plano de carreiras com o objetivo de preparar as pessoas para ocuparem cargos mais altos no futuro, dentro de suas hierarquias organizacionais.

Segundo Dutra (2010), a carreira organizacional foi mais predominante antigamente, mas as empresas continuaram a influenciar as carreiras de seus funcionários. Contudo, as organizações já não conseguem mais oferecer carreiras vitalícias e as pessoas não podem ter oportunidades profissionais de longo prazo. É nesse contexto que surgem as carreiras sem fronteiras em oposição às carreiras organizacionais, explorando um significado novo de organização e apresentando uma nova visão sobre carreira.

\subsubsection{Carreiras Sem Fronteiras}

Com o mundo globalizado, complexo e individualista, tornou-se difícil para as organizações o gerenciamento das carreiras de seus funcionários. Nesse contexto, surge o conceito de carreiras sem fronteiras devido às transformações nas relações de trabalho ocasionadas pela mudança da sociedade industrial para a nova economia (VELOSO, DUTRA E NAKATA, 2008). O tradicional plano de carreira está sendo substituído para o autogerenciamento da carreira, ou seja, agora quem precisa se preocupar com sua carreira é o indivíduo e não mais as empresas. Cada pessoa deve administrar sua própria carreira e ajustá-la às exigências de um ambiente em veloz transformação (CHIAVENATO, 2010).

Veloso, Dutra e Nakata (2008) defendem que, atualmente, trabalhar não significa ter um emprego fixo em uma empresa e, com isso, o desenvolvimento profissional requer adaptações sociais que envolvam o trabalhador e sua família. Assim, surgem outras formas de carreira devido ao dinamismo, que influencia o comportamento das pessoas e as organizações.

As carreiras sem fronteiras surgem nesse cenário, originadas não somente por fatores ligados a mudanças de comportamento dos trabalhadores, mas também pelas necessidades das organizações de se manterem competitivas, 
com quadros funcionais enxutos e flexíveis (DUTRA, 2010, p.18).

$\mathrm{Na}$ carreira sem fronteiras, as pessoas são responsáveis por suas próprias carreiras, podendo atuar de forma autônoma com seu próprio planejamento, e passam a cultivar networks e buscar constantemente acesso ao conhecimento e recursos de outras pessoas, além das fronteiras da organização. Essas carreiras são desenvolvidas por meio do aprendizado coletivo, e para o profissional sem fronteiras, o aprendizado é um fator chave para o seu desenvolvimento profissional e para sua carreira (DUTRA, 2010).

$\mathrm{Na}$ tabela a seguir são apresentadas as tendências que transformaram as carreiras sem fronteiras em relação à pessoa e à organização.

Tabela 5: Tendências da transformação das carreiras sem fronteiras

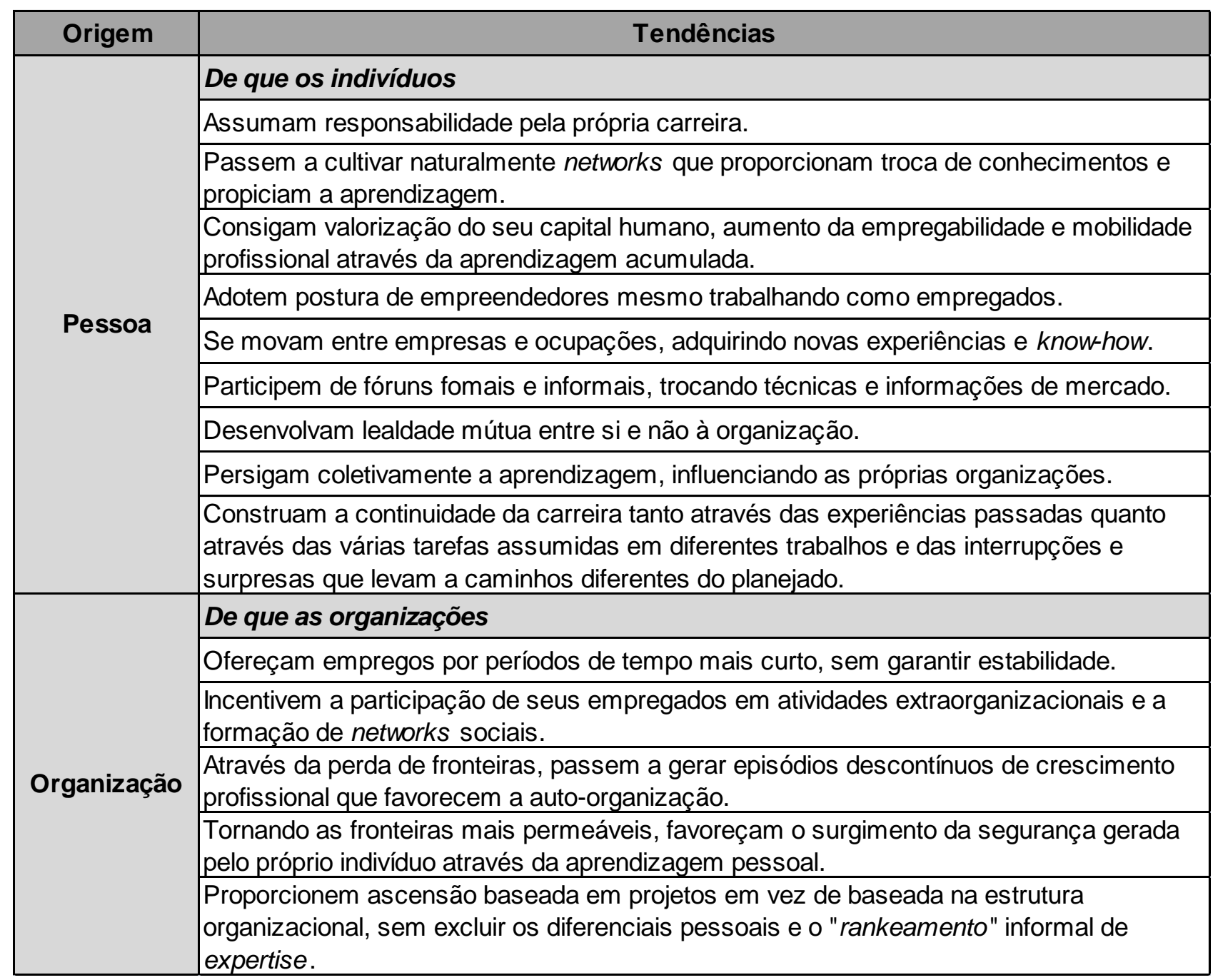

Fonte: Dutra (2010, p.26) 
Assim como as carreiras sem fronteiras, as carreiras proteanas também se opõem às carreiras organizacionais, visto que elas também são administradas pelas pessoas e não pelas empresas.

\subsubsection{Carreiras Proteanas}

A carreira proteana consiste em todas as experiências de uma pessoa. Ela é desenvolvida mais pelo indivíduo do que pela organização, e pode ser redirecionada de acordo com as necessidades desse indivíduo (MARTINS, 2010).

\footnotetext{
O profissional proteano consegue se ajustar às demandas do ambiente de carreiras, com flexibilidade e investimento em suas habilidades, qualificações e competências, mas sempre tendo consciência dos seus objetivos individuais (MARTINS, 2010, p.29).
}

O que move esse tipo de carreira são as necessidades pessoais e o sucesso psicológico, o que é diferente de sucesso exterior. Ela se dá pela mudança de segurança e emprego de longo prazo para contratos de curto prazo. Suas características principais são constantes mudanças, autoinvenção, autonomia, autodireção, habilidades para aprender, para direcionar carreira e vida, e construir relações (DUTRA, 2010).

Tabela 6: Características da carreira proteana

\begin{tabular}{|c|c|}
\hline Dimensão & Característica \\
\hline Objetivo & Sucesso psicológico \\
\hline Carreira & $\begin{array}{l}\text { Administrada pelo indivíduo e não pela organização } \\
\text { Estende-se por toda a vida como uma série de mudanças } \\
\text { de identidade e aprendizado contínuo }\end{array}$ \\
\hline O que conta & $\dot{E}$ a idade da carreira e não a idade cronológica \\
\hline Organização & Provê trabalhos desafiadores e relacionamentos \\
\hline Desenvolvimento & $\begin{array}{l}\text { Não é necessariamente treinamento formal, readaptação } \\
\text { e mobilidade vertical }\end{array}$ \\
\hline Perfil de sucesso & $\begin{array}{l}\text { Do know-how para o learn-how } \\
\text { Da segurança no trabalho para a empregabilidade } \\
\text { Das carreiras organizacionais para as carreiras proteanas } \\
\text { Da individualidade no trabalho para a individualidade no } \\
\text { todo }\end{array}$ \\
\hline
\end{tabular}

Fonte: Mósca, Cereja e Bastos (2014, p.49)

As organizações devem se preocupar com os programas de gestão de carreira que promovam autonomia e independência dos profissionais proteanos. 
Ao contrário da forma tradicional e burocrática, as empresas devem estimular ações de reconhecimento, interação e flexibilidade com uma cultura de aprendizagem e motivação para conseguir reter esses profissionais. Eles precisam ver que são úteis e que estão colaborando para o crescimento da organização (MÓSCA, CEREJA E BASTOS, 2014).

De acordo com Ferreira (2013), no atual mundo globalizado, a função da área de gestão de pessoas é atrair e reter talentos, possibilitando crescimento profissional e treinamento e desenvolvimento. Para isso, é necessário que haja um bom ambiente de trabalho em termo físicos e psicológicos.

\subsection{Ambiente Organizacional}

\subsubsection{Clima Organizacional}

Segundo Luz (2003), clima organizacional consiste no grau de satisfação dos funcionários em um ambiente organizacional em determinado período. Para Veloso, Dutra e Nakata (2008), o clima organizacional é constituído pelos sentimentos dos funcionários em relação à organização. Esses sentimentos podem ser positivos ou negativos, e impactam diretamente no desempenho e no comportamento das pessoas. Um bom clima organizacional pode contribuir para que as estratégias da empresa sejam bem sucedidas (MÓSCA, CEREJA E BASTOS, 2014).

Alguns fatores considerados pelo clima organizacional são listados por Ferreira (2013) e dizem respeito a:

- À empresa, com seu modelo de gestão, sua missão, sua comunicação interna, e sua forma de tomada de decisões;

- Ao relacionamento dos empregados com seus líderes;

- Às práticas de gestão de pessoas, como, por exemplo, remuneração e valorização dos funcionários.

A missão da área de Gestão de Pessoas das organizações é motivar os funcionários e torná-los satisfeitos, então, é preciso diagnosticar o clima organizacional com frequência para saber se está cumprindo sua missão. Além disso, esse diagnóstico auxilia na realização de melhorias no ambiente organizacional, que impactam no melhor desempenho das pessoas e nos resultados da empresa. Nesse contexto, Ferreira (2013, p.47) afirma que há uma forte relação entre clima e motivação: 
O ambiente das organizações influencia a motivação, pois 0 clima é a "qualidade" do ambiente organizacional que é percebida ou experimentada por seus integrantes e influencia o seu comportamento. Se as pessoas não estão motivadas ou felizes em pertencer a uma organização, seu clima deve ser estudado. É por meio do clima organizacional que se expressam as percepções das pessoas em relação às organizações em que trabalham.

Para Luz (2003), o clima organizacional pode ser considerado bom, prejudicado ou ruim. O clima é bom quando há atitudes positivas no ambiente organizacional, como indicação de funcionários para amigos e familiares e quando eles sentem orgulho de fazerem parte da organização. Nesse tipo de clima, a rotatividade dos funcionários é baixa e o tempo de permanência na empresa é alto. O clima prejudicado ou ruim é quando afeta o ânimo dos funcionários, acarretando em tensões, rivalidades, conflitos, entre outros. Isso não é favorável para os funcionários e nem para os objetivos das organizações.

Para esse autor, é possível medir o clima organizacional porque ele se materializa e se tangibiliza através de indicadores, os quais são capazes de identificar as causas que afetam o clima, e também servem para alertar a empresa quando ele não está bom. Os indicadores são:

- Turnover (rotatividade de pessoas): quando alto, pode indicar que as pessoas não são comprometidas com a empresa e que falta algo para satisfazê-las;

- Absenteísmo (faltas): também pode indicar falta de comprometimento dos funcionários com a empresa;

- Pichações nos banheiros: funcionários podem degradar o patrimônio da empresa por se sentirem seguros dentro dos banheiros para xingar os gestores ou a empresa;

- Programa de sugestões: quando malsucedidos podem indicar falta de qualidade nas sugestões apresentadas pelos funcionários;

- Avaliação de desempenho: quando o desempenho está ruim pode indicar que o clima também está ruim;

- Greves: podem revelar insatisfação dos funcionários e o seu descontentamento com a empresa;

- Conflitos interpessoais e interdepartamentais: os conflitos entre as pessoas e entre os departamentos de uma empresa podem criar um clima tenso ou agradável;

- Desperdícios de material: desperdiçar materiais pode constituir uma forma de reação dos funcionários em relação às condições de trabalho; 
- Queixas no Serviço Médico: os funcionários podem usar os consultórios médicos para falar sobre suas apreensões e descontentamentos em relação à empresa.

Dessa forma, é muito importante as organizações realizarem pesquisa de clima, pois ela ajuda no planejamento e na implementação de ações que visam melhorar o ambiente interno da organização, identificando pontos fortes que precisam ser intensificados e pontos fracos que precisam ser reparados. Além disso, a pesquisa de clima possibilita a participação dos funcionários, os quais se sentem valorizados e ouvidos pela empresa, impactando em sua satisfação e produtividade (FERREIRA, 2013).

Para a autora, o clima organizacional é muito influenciado pelo conceito de qualidade de vida no trabalho e, segundo é afirmado por Albuquerque e França (1998), as preocupações com essa qualidade de vida estão ganhando força no ambiente empresarial brasileiro.

\subsubsection{Qualidade de Vida no Trabalho}

Segundo Ferreira (2013), o termo qualidade de vida no trabalho (QVT) foi usado pela primeira vez em 1950 por Eric Trist e outros pesquisadores do Instituto Tavistock e seu foco era melhorar a produtividade, diminuir conflitos e auxiliar a vida dos trabalhadores, levando em consideração o indivíduo, o trabalhador e a organização. O movimento de QVT emergiu para equilibrar a vida pessoal e profissional dos trabalhadores. Contudo, a maior atenção das empresas em relação à QVT surgiu mesmo na década de 1960 quando houve maior preocupação com os desdobramentos do emprego na saúde e no bemestar dos trabalhadores.

Para Chiavenato (2010), o termo qualidade de vida no trabalho está relacionado aos aspectos físicos, ambientais e psicológicos no ambiente de trabalho. Para este autor, a QVT se posiciona de um lado os anseios dos empregados, como bem-estar e satisfação no trabalho, e por outro lado, os interesses organizacionais, como produtividade e qualidade das atividades desempenhadas por seus funcionários.

A qualidade de vida no trabalho gera benefícios para todos os envolvidos na organização e auxilia em maior produtividade, menos dias de afastamento de seus funcionários por algum motivo relacionado à doença e gera maior engajamento das pessoas, contribuindo assim, para o resultado financeiro da organização (MÓSCA, CEREJA E BASTOS, 2014). Se uma empresa quer ser 
mais produtiva e competitiva no mercado, ela precisa promover a melhoria da qualidade de vida de seus funcionários para aumentar sua satisfação no trabalho, sua motivação e seu comprometimento, o que, consequentemente, melhora o posicionamento competitivo da empresa (FERREIRA, 2013).

\begin{abstract}
Quando uma pessoa está satisfeita com o trabalho tende a ser mais comprometida e dedicada, porém, quando insatisfeita, tende a faltar, a se atrasar, a ter baixo envolvimento, a procurar novas oportunidades e até mesmo a se demitir. A insatisfação no trabalho pode levar ao absenteísmo e à rotatividade e trazer uma série de doenças como estresse, problemas de coração, pressão e úlceras, tudo isso devido a tensão e pressão do ambiente de trabalho, que podem gerar elevados gastos com assistência médica nas organizações (FERREIRA, 2013, p.117).
\end{abstract}

Segundo a autora, na gestão da qualidade de vida no trabalho, uma empresa pode atuar em três focos principais:

- Estratégico: quando a empresa declara em sua missão e em sua política a preocupação com a QVT.

- Gerencial: quando os líderes de uma empresa tornam-se responsáveis pela gestão da QVT, que está associada a objetivos, metas e produtividade.

- Operacional: quando existem ações visando ao bem-estar, mas sem estarem alinhadas aos objetivos relacionados à competitividade, produtividade e desempenho no trabalho.

Os programas de QVT desenvolvidos pelas organizações visam a implantação de ações para promover a saúde de seus funcionários, como: "lazer, saúde e segurança, atendimento clínico e educação para a saúde, assistência psicológica, produtividade, redução de acidentes, absenteísmo e preservação do meio ambiente (FERREIRA, 2013, p. 126). Ainda segundo essa autora, existem alguns programas exigidos por lei (Programa de Controle Médico de Saúde Ocupacional, Programa de Prevenção de Riscos Ambientais, Comissão Interna de Prevenção de Acidentes e Semana Interna de Prevenção de Acidentes no Trabalho) e outros que variam de empresa para empresa e podem envolver ginástica laboral, ambulatório médico, alimentação e saúde dos empregados e familiares, grêmio esportivo, campanhas de conscientização, entre outros.

O Programa de Controle Médico de Saúde Ocupacional (PCMSO) tem como objetivo promover e prevenir a saúde dos trabalhadores, prevenir e diagnosticar doenças que podem ser relacionadas às funções desempenhadas 
no trabalho. O Programa de Prevenção de Riscos Ambientais (PPRA) tem o intuito de garantir a preservação da saúde e integridade dos trabalhadores em relação aos riscos existentes no ambiente de trabalho. A CIPA (Comissão Interna de Prevenção de Acidentes) é representada por funcionários e tem como objetivo proporcionar um trabalho mútuo entre empregados e empregadores na prevenção de acidentes e melhorar a qualidade do ambiente de trabalho, promovendo a saúde dos envolvidos. Já a Semana Interna de Prevenção de Acidentes no Trabalho (SIPAT) possui como propósito orientar e conscientizar os funcionários sobre a importância de prevenir acidentes e doenças no ambiente de trabalho, incentivando-os a praticar a segurança dentro da empresa. 


\section{Métodos e procedimentos de coleta e de análise de dados do estudo}

\subsection{Etapas, Procedimentos e Instrumentos de coleta de dados}

Para este estudo foi realizada uma pesquisa descritiva que, segundo Vergara (2004), tem o objetivo de expor as características de uma população, fenômeno ou estabelecer associações entre variáveis. Para chegar ao intuito do estudo, foi feita uma pesquisa de campo através da aplicação de um questionário, o qual visa traduzir os objetivos da pesquisa em questões (GIL, 2008), sendo utilizada a ferramenta Qualtrics para o desenvolvimento do questionário.

Para a construção do instrumento de coleta de dados, foi realizada uma pesquisa bibliográfica a partir de materiais publicados em livros, revistas e redes eletrônicas (VERGARA, 2004) sobre a Geração Y e as práticas de Gestão de Pessoas, que serviram de base a formulação do instrumento de coleta de dados. A pesquisa bibliográfica permite um maior alcance dos fenômenos do que fazer uma pesquisa direta (GIL, 2008).

Para que a coleta de dados ocorresse de forma adequada, antes de ser aplicado o questionário, foi realizado um pré-teste com o objetivo de apresentar possíveis falhas na elaboração das questões, como complexidade, imprecisão e exaustão, entre outras, possibilitando uma maior adequação do instrumento de coleta de dados (GIL, 2008). O pré-teste foi feito com quatro pessoas que fazem parte do público alvo e, a partir dele, foram detectadas algumas necessidades de ajustes, sendo o instrumento de coleta de dados aplicado e disponibilizado no Apêndice 1.

O universo da pesquisa foi composto por formandos do último ano do curso de Administração da PUC-Rio, com previsão de formatura em 2015.2 ou 2016.1, e que já trabalharam ou fizeram estágio. Para o levantamento do total de estudantes nesse perfil, foram analisadas a quantidade de alunos que se formam por período e o número de convocados para o Enade (Exame Nacional de Desempenho dos Estudantes) do ano de 2015, bem como informações da 
secretaria do curso de Administração da PUC-Rio. Foi calculado como universo do estudo, aproximadamente, 200 alunos, sendo 60 o tamanho da amostra dessa pesquisa. Tratou-se de uma amostra não probabilística, não sendo baseada em fundamentação matemática ou estatística, e sim em critérios do pesquisador, sendo utilizada uma amostra por conveniência considerando pessoas de fácil acesso a ele (GIL, 2008). O questionário foi respondido de duas formas: via Qualtrics (tendo sido o link disponibilizado via redes sociais), e outra via papel dentro das salas de aula e no departamento IAG de Administração da PUC-Rio.

O questionário foi dividido em três blocos. O primeiro bloco tinha 0 objetivo de entender o perfil dos respondentes e contava com três perguntas filtro para obter somente os alunos dentro do perfil desejado. A primeira pergunta tinha o objetivo de identificar os alunos de Administração da PUC-Rio, e caso a resposta fosse negativa, o questionário se encerrava. A segunda pergunta era para identificar se o aluno de Administração se formaria no final de 2015 ou no meio de 2016 e, caso a resposta fosse negativa, o questionário se encerrava. A terceira pergunta filtro servia para permitir que prosseguissem apenas os alunos que estivessem dentro do universo de pesquisa delimitado, utilizando-se uma pergunta sobre experiência profissional de trabalho e/ou estágio dos respondentes, e caso a resposta fosse negativa, ou seja, que não tinha nenhuma experiência, o questionário era encerrado. Assim, 60 respondentes constituem a amostra do presente estudo. As perguntas seguintes visavam identificar o perfil mais detalhado dos respondentes.

O segundo bloco visava entender se os respondentes concordavam ou discordavam de 22 afirmações sobre as quatro práticas de Gestão de Pessoas (treinamento e desenvolvimento, carreiras, clima organizacional e qualidade de vida no trabalho) apresentadas na parte teórica desse estudo. O terceiro bloco apresentava essas práticas em quatro frases e pedia que os respondentes as ordenassem, por grau de importância, considerando suas experiências de trabalho e/ou estágio.

\subsection{Limitações do Estudo}

O presente estudo apresenta algumas limitações, como em relação às práticas de Gestão de Pessoas estudadas por não abordar a totalidade de atividades desempenhadas pela área de Gestão de Pessoas, considerando apenas treinamento e desenvolvimento, carreiras (organizacionais, sem 
fronteiras e proteanas), clima organizacional, e qualidade de vida no trabalho, por serem práticas mais relacionadas aos anseios da Geração Y, conforme apresentado no referencial teórico.

Existe também uma limitação no próprio instrumento de coleta de dados, o questionário, pois ele não permite verificar aspectos mais qualitativos, como o aprofundando de questões relacionadas às práticas de Gestão de Pessoas. Além disso, outra limitação do questionário corresponde ao comprometimento por parte dos respondentes, que podem não responder com sinceridade as perguntas, além do fato que alguns começam a responder e desistem, o que impacta no tamanho da amostra.

Contudo, apesar de todas essas limitações, o presente estudo mostrou-se interessante ao apresentar informações relevantes sobre essa nova geração que está cada vez mais presente no ambiente organizacional. 


\section{Apresentação e análise dos resultados}

\subsection{Descrições dos resultados}

Este capítulo apresenta e analisa os resultados obtidos através da pesquisa, considerando o referencial teórico adotado no presente estudo. 78 pessoas iniciaram o questionário, mas somente 60 o concluíram. As questões foram formuladas considerando os quatro temas de Gestão de Pessoas abordados no referencial teórico: treinamento e desenvolvimento, carreiras (organizacionais, sem fronteiras e proteanas), clima organizacional e qualidade de vida no trabalho.

\subsubsection{Descrição do perfil dos respondentes}

Os 60 respondentes são alunos de Administração da PUC-Rio, sendo 33\% formandos do segundo semestre de 2015 e $67 \%$ formandos do primeiro semestre de 2016.

Tabela 7: Formação dos respondentes

\begin{tabular}{|c|l|c|c|c|}
\hline$\#$ & Resposta & Resposta & $\%$ \\
\hline 1 & Sim, no final de 2015 & 20 & $33 \%$ \\
2 & Sim, no meio de 2016 & 40 & $67 \%$ \\
3 & Não & 0 & $0 \%$ \\
\hline & Total & 60 & $100 \%$ \\
\hline
\end{tabular}

Fonte: Próprio autor (2015)

Todos os respondentes já tiveram alguma experiência de trabalho e/ou estágio. A maioria já trabalhou ou fez estágio, o que compõe $58 \%$ da amostra, $12 \%$ somente trabalhou e $30 \%$ somente fez estágio. Quando perguntados em qual tipo de empresa fizeram estágio e/ou trabalharam, $87 \%$ indicou empresa privada, 7\% empresa pública, 2\% ONG (Organizações Não Governamentais) e $5 \%$ outros tipos de empresa, como as mistas (privadas e públicas). 
Tabela 8: Tipos de empresas

\begin{tabular}{|c|l|c|c|c|}
\hline$\#$ & Resposta & & Resposta & $\%$ \\
\hline 1 & Privada & 52 & $87 \%$ \\
2 & Pública & 4 & $7 \%$ \\
3 & ONG (Organizações não & & 1 & $2 \%$ \\
\hline & governamentais) & 3 & $5 \%$ \\
\hline & Outros: & 60 & $100 \%$ \\
\hline
\end{tabular}

Fonte: Próprio Autor (2015)

Quando perguntados se trabalham ou fazem estágio atualmente, 30\% respondeu que trabalha, 35\% que faz estágio e 35\% que não trabalha e não faz estágio.

Tabela 9: Atividades realizadas atualmente pelos respondentes

\begin{tabular}{|c|l|c|c|c|}
\hline$\#$ & Resposta & Resposta & $\%$ \\
\hline 1 & Sim, trabalho & & 18 & $30 \%$ \\
2 & Sim, faço estágio & & 21 & $35 \%$ \\
3 & Não & 21 & $35 \%$ \\
\hline & Total & 60 & $100 \%$ \\
\hline
\end{tabular}

Fonte: Próprio Autor (2015)

Para concluir o perfil dos respondentes, foi perguntado o gênero, onde $58 \%$ são mulheres e $42 \%$ são homens. A faixa etária mais frequente foi de $24-29$ anos com $55 \%$, em seguida, com $42 \%$ foi entre $18-23$ e $3 \%$ entre $30-35$.

\subsubsection{Práticas de Gestão de Pessoas e Geração Y}

Como apresentado anteriormente na tabela 9, dos respondentes, atualmente 30\% trabalha, 35\% faz estágio e 35\% não trabalha e não faz estágio.

Aos que não trabalham e não fazem estágio, foi perguntado por qual(is) motivo(s) saíram da empresa em que estavam e para os que responderam que fazem estágio ou trabalham atualmente, por qual(is) motivo(s) sairiam da empresa.

Para os respondentes que não trabalham e não fazem estágio atualmente, os maiores motivos para deixarem a empresa em que estavam foram a falta de oportunidade de crescimento (43\%) e a vontade de assumir novos desafios (43\%), conforme é apresentado na tabela 10. 
Tabela 10: Motivos de saída da empresa dos respondentes que não trabalham e não fazem estágio

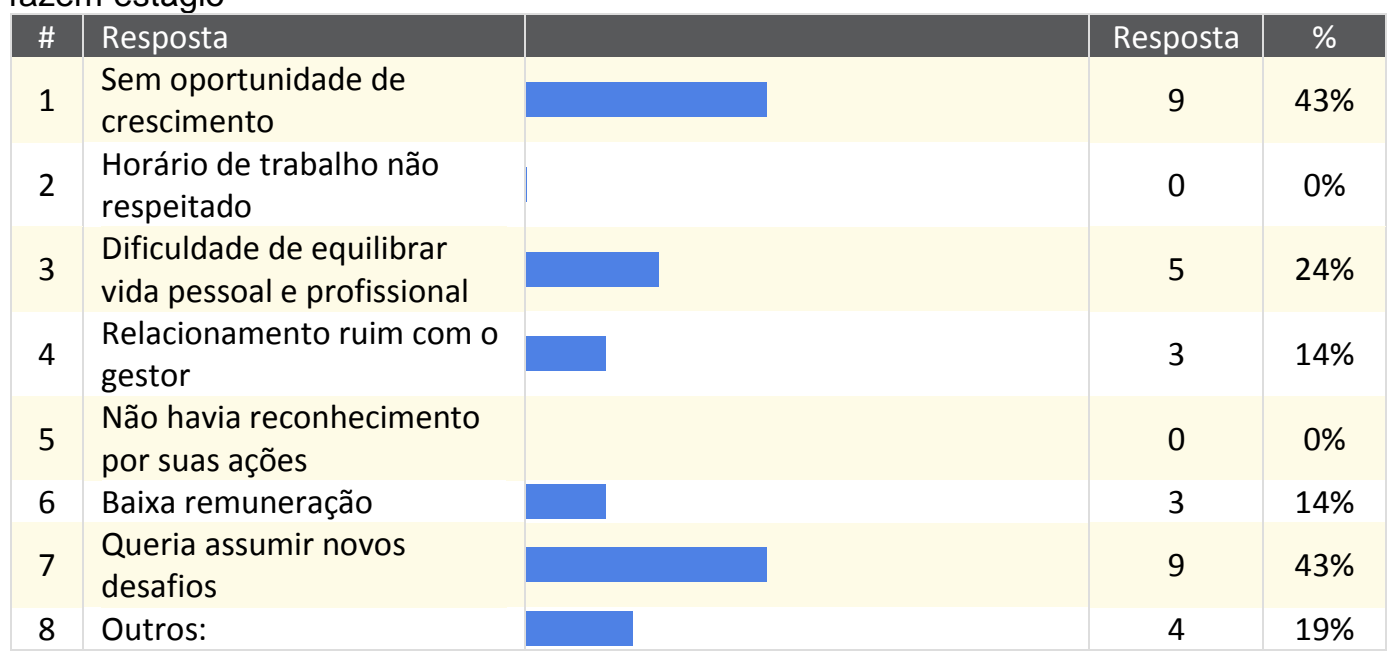

Fonte: Próprio Autor (2015)

Para aqueles que trabalham ou fazem estágio atualmente, o maior motivo que os levariam a sair da atual empresa é a vontade de assumir novos desafios (51\%) seguido de falta de oportunidade de crescimento (49\%). Os motivos dos respondentes que saíram da empresa e os motivos dos respondentes que sairiam da empresa atual foram semelhantes, mas para esses últimos, a baixa remuneração ( $41 \%)$ também é um fator relevante que os levaria a buscar novas oportunidades.

Tabela 11: Motivos dos respondentes que trabalham ou fazem estágio para saírem da atual empresa

\begin{tabular}{|c|l|c|c|}
\hline$\#$ & Resposta & Resposta & $\%$ \\
\hline 1 & $\begin{array}{l}\text { Sem oportunidade de } \\
\text { crescimento }\end{array}$ & 19 & $49 \%$ \\
\hline 2 & $\begin{array}{l}\text { Horário de trabalho não } \\
\text { respeitado }\end{array}$ & 6 & $15 \%$ \\
\hline $\begin{array}{l}\text { Dificuldade de equilibrar } \\
\text { vida pessoal e profissional }\end{array}$ & & 6 & $15 \%$ \\
\hline 4 & $\begin{array}{l}\text { Relacionamento ruim com o } \\
\text { gestor }\end{array}$ & 6 & $15 \%$ \\
\hline 5 & $\begin{array}{l}\text { Não há reconhecimento por } \\
\text { suas ações }\end{array}$ & 8 & $21 \%$ \\
6 & Baixa remuneração & 16 & $41 \%$ \\
7 & Quer assumir novos desafios & 20 & $51 \%$ \\
8 & Outros: & 4 & $10 \%$ \\
\hline
\end{tabular}

Fonte: Próprio Autor (2015)

Essa vontade de assumir novos desafios observada nas respostas desta pesquisa é explicada por Oliveira (2010) ao falar das características da Geração Y. Para ele, os jovens dessa geração são movidos por novos desafios que 
promovam seu desenvolvimento profissional e, caso percebam que não há possibilidade de crescimento na empresa, buscarão novos desafios fora dela, como pode ser visto nas respostas.

Essa busca por crescimento e novos desafios também é evidenciada por Sá, Lemos e Cavazotte (2014) ao mostrarem que os jovens da Geração Y desejam crescer e fazer carreira rapidamente. Para Dutra (2010), usar a empresa como referência para carreira está sendo substituído por carreiras que usam as próprias pessoas e as oportunidades do mercado para construção de futuro, ou seja, própria carreira.

A questão seguinte perguntou há quanto tempo os respondentes estão ou estiveram em seus últimos trabalhos ou estágios e 53\% respondeu entre 1 e 2 anos, o que pode estar atrelado ao prazo máximo de estágio, que corresponde a dois anos, mas também indica que os jovens dessa geração não estão ficando muito tempo na empresa como as gerações anteriores. Para Mósca, Cereja e Bastos (2014) é difícil a Geração Y ficar mais de dois anos no mesmo cargo. De acordo com Oliveira (2010), essa geração possui projeto de vida de curto prazo. Ainda sobre o tempo de permanência na empresa, $22 \%$ responderam que estiveram/estão entre 0 e 5 meses na empresa, 18\% entre 6 e 11 meses, e apenas $7 \%$ acima de 3 anos.

Outra característica da Geração Y afirmada por Santos (2011) é que essa geração está em busca do equilíbrio entre vida pessoal e profissional. No questionário, $87 \%$ dos respondentes relatam conseguir equilibrar vida pessoal e profissional e apenas 13\% não consegue, mas estão em busca desse equilíbrio.

Para avaliar de forma mais específica as práticas de Gestão de Pessoas mais valorizadas pela Geração Y, foram elaboradas 22 afirmações das quatro práticas abordadas neste estudo para identificar o quanto os respondentes concordam ou discordam delas. Para uma melhor análise, foram agrupadas as respostas concordo totalmente com concordo parcialmente como positivas e as respostas discordo parcialmente com discordo totalmente como negativas.

Em relação à prática de treinamento e desenvolvimento realizada pelas organizações, é possível perceber, tal qual apresentado na tabela 12, que as afirmações referentes ao tema tiveram uma boa aceitação dos respondentes. De acordo com as respostas, $100 \%$ concordam que é importante ter treinamentos e se desenvolver no ambiente organizacional, 95\% concordam que os treinamentos oferecidos pela empresa aumentam seu desempenho nas atividades profissionais e $98 \%$ concordam que é importante crescer com a empresa, desenvolvendo-se constantemente. Retomando Oliveira (2010) 
percebe-se que as respostas encontradas respaldam a informação do autor que afirma que a Geração Y está sempre em busca de adquirir novos conhecimentos e se desenvolver profissionalmente. Atrelado a isso, Gil (2001) afirma que treinamento e desenvolvimento oferecem experiências de aprendizagem, gerando oportunidades de crescimento e desenvolvimento profissional, que são itens bastante valorizados pelos integrantes dessa geração.

Para Oliveira (2010), devido à educação moldada em recompensas e punições que os jovens dessa geração vivenciaram na infância, originou-se neles uma necessidade constante de reconhecimento, o que pode explicar os $100 \%$ dos respondentes que buscam empresas que usam mecanismos para reconhecer e valorizar seus funcionários.

Tabela 12: Respostas das afirmações sobre treinamento e desenvolvimento

\begin{tabular}{|l|c|c|}
\hline \multicolumn{1}{|c|}{ Pergunta } & $\begin{array}{c}\% \\
\text { Positivas }\end{array}$ & $\begin{array}{c}\% \\
\text { Negativas }\end{array}$ \\
\hline $\begin{array}{l}\text { Considero importante a possibilidade de ter treinamentos e me } \\
\text { desenvolver no ambiente organizacional. }\end{array}$ & $100 \%$ & $0 \%$ \\
\hline $\begin{array}{l}\text { Acredito que os treinamentos oferecidos pela empresa aumentam } \\
\text { meu desempenho nas atividades profissionais. }\end{array}$ & $95 \%$ & $5 \%$ \\
\hline $\begin{array}{l}\text { Busco empresas que usam mecanismos para reconhecer e valorizar } \\
\text { seus funcionários. }\end{array}$ & $100 \%$ & $0 \%$ \\
\hline $\begin{array}{l}\text { Considero importante crescer juntamente com a empresa, } \\
\text { desenvolvendo-me constantemente. }\end{array}$ & $98 \%$ & $2 \%$ \\
\hline
\end{tabular}

Fonte: Próprio Autor (2015)

Em relação ao tema carreiras, foram abordadas três tipos: organizacionais, sem fronteiras e proteanas. Em relação às características das carreiras organizacionais, $62 \%$ dos respondentes concordam que preferem se desenvolver dentro da organização do que fora dela, $63 \%$ concordam que pretendem construir carreira na empresa e chegar ao topo da hierarquia e apenas $37 \%$ concordam que preferem estabilidade e segurança à liberdade e autonomia, conforme tabela 13.

Tabela 13: Respostas das afirmações sobre carreiras organizacionais

\begin{tabular}{|l|c|c|}
\hline \multicolumn{1}{|c|}{ Pergunta } & $\begin{array}{c}\% \\
\text { Positivas }\end{array}$ & $\begin{array}{c}\% \\
\text { Negativas }\end{array}$ \\
\hline Prefiro me desenvolver dentro da organização do que fora dela. & $62 \%$ & $38 \%$ \\
\hline $\begin{array}{l}\text { Pretendo construir carreira na empresa em que trabalho/faço estágio, } \\
\text { ou que viso trabalhar, e chegar ao topo da hierarquia. }\end{array}$ & $63 \%$ & $37 \%$ \\
\hline $\begin{array}{l}\text { Prefiro estabilidade (ficar na empresa um longo período) e segurança } \\
\text { do que liberdade e autonomia. }\end{array}$ & $37 \%$ & $63 \%$ \\
\hline
\end{tabular}

Fonte: Próprio Autor (2015) 
Contudo, a organizacional não foi o tipo de carreira que predominou no questionário. Isso também é evidenciado por Veloso, Dutra e Nakata (2008), que afirmam que no mundo empresarial de hoje, a carreira organizacional não é a opção que prevalece, pois as pessoas tornaram-se responsáveis por suas evoluções profissionais (DUTRA, 2010).

Quanto ao tema de carreiras sem fronteiras, representado na tabela 14, 90\% dos respondentes preferem interagir com pessoas e empresas além das fronteiras de suas organizações. Para Oliveira (2010) a Geração Y valoriza muito os relacionamentos e a integração com as pessoas, e são ansiosos por crescimento rápido $\mathrm{e}$, por isso, muitos saem das empresas quando não percebem esse crescimento (SANTOS, 2011), o que explica os $93 \%$ dos respondentes preferirem sair da empresa se não houver oportunidades de desenvolvimento. Contudo, metade dos respondentes (50\%) concorda que preferem trabalhar com o próprio planejamento do que trabalhar dentro de uma empresa.

Tabela 14: Respostas das afirmações sobre carreiras sem fronteiras

\begin{tabular}{|l|c|c|}
\hline \multicolumn{1}{|c|}{ Pergunta } & $\begin{array}{c}\% \\
\text { Positivas }\end{array}$ & $\begin{array}{c}\% \\
\text { Negativas }\end{array}$ \\
\hline $\begin{array}{l}\text { Prefiro interagir com pessoas e empresas além das fronteiras da } \\
\text { minha organização. }\end{array}$ & $90 \%$ & $10 \%$ \\
\hline $\begin{array}{l}\text { Prefiro sair da empresa em que estou se não houver oportunidades } \\
\text { de desenvolvimento constantes. }\end{array}$ & $93 \%$ & $7 \%$ \\
\hline $\begin{array}{l}\text { Prefiro trabalhar com meu próprio planejamento a trabalhar dentro de } \\
\text { uma empresa. }\end{array}$ & $50 \%$ & $50 \%$ \\
\hline
\end{tabular}

Fonte: Próprio Autor (2015)

Em comparação aos outros tipos de carreiras, as características das carreiras proteanas foram as que mais os respondentes se identificaram. Conforme tabela $15,100 \%$ deles concordam que utilizam sempre suas competências e habilidades para atingir seus objetivos de carreira e de vida. Segundo Dutra (2010), nesse tipo de carreira há uma mudança de emprego de longo prazo para contratos de curto prazo, o que representa uma característica da Geração Y indicada por Oliveira (2010) ao afirmar que os jovens dessa geração possuem projetos de vida de curto prazo. Isso pode ajudar a explicar os resultados de $95 \%$ dos respondentes que concordaram que buscam oportunidades de carreiras baseadas em seus valores pessoais, dentro ou fora da empresa e de $92 \%$ preferirem sair da empresa se o cargo não se aproximar de suas necessidades pessoais de carreira e de sucesso. 
Tabela 15: Respostas das afirmações sobre carreiras proteanas

\begin{tabular}{|l|c|c|}
\hline \multicolumn{1}{|c|}{ Pergunta } & $\begin{array}{c}\% \\
\text { Positivas }\end{array}$ & $\begin{array}{c}\% \\
\text { Negativas }\end{array}$ \\
\hline $\begin{array}{l}\text { Utilizo sempre minhas competências e habilidades para atingir meus } \\
\text { objetivos de carreira e de vida. }\end{array}$ & $100 \%$ & $0 \%$ \\
\hline $\begin{array}{l}\text { Busco oportunidades de carreiras baseadas em meus valores } \\
\text { pessoais, dentro ou fora da empresa. }\end{array}$ & $95 \%$ & $5 \%$ \\
\hline $\begin{array}{l}\text { Prefiro sair da empresa em que estou se o meu cargo não se } \\
\text { aproximar das minhas necessidades pessoais de carreira e de } \\
\text { sucesso. }\end{array}$ & $92 \%$ & $8 \%$ \\
\hline
\end{tabular}

Fonte: Próprio Autor (2015)

Em relação ao clima organizacional e qualidade de vida no trabalho, as respostas foram muito positivas. Dos respondentes, $97 \%$ preferem um ambiente agradável para desenvolver suas atividades profissionais. Isso pode ser explicado por Sá, Lemos e Cavazotte (2014) ao afirmaram que os jovens da Geração $\mathrm{Y}$ valorizam um bom ambiente de trabalho.

Para $100 \%$ dos respondentes, um bom clima organizacional impacta em seu desempenho e nos resultados da empresa e $98 \%$ sentem-se mais motivados e satisfeitos com um bom clima de trabalho. 100\% consideram importante receber feedbacks constantes sobre suas atividades, o que, segundo Oliveira (2010) é explicado na infância da Geração Y que aprendeu a receber feedbacks de todas as suas ações.

Tabela 16: Respostas das afirmações sobre clima organizacional

\begin{tabular}{|l|c|c|}
\multicolumn{1}{|c|}{ Pergunta } & $\begin{array}{c}\% \\
\text { Positivas }\end{array}$ & $\begin{array}{c}\% \\
\text { Negativas }\end{array}$ \\
\hline $\begin{array}{l}\text { Prefiro um ambiente agradável para desenvolver minhas atividades } \\
\text { profissionais. }\end{array}$ & $97 \%$ & $3 \%$ \\
\hline $\begin{array}{l}\text { Acredito que um bom clima organizacional impacta no meu } \\
\text { desempenho e nos resultados da empresa. }\end{array}$ & $100 \%$ & $0 \%$ \\
\hline $\begin{array}{l}\text { Sinto-me mais motivado(a) e satisfeito(a) com um bom clima de } \\
\text { trabalho. }\end{array}$ & $98 \%$ & $2 \%$ \\
\hline $\begin{array}{l}\text { Considero importante receber feedbacks constantemente sobre } \\
\text { minhas atividades. }\end{array}$ & $100 \%$ & $0 \%$ \\
\hline $\begin{array}{l}\text { Considero importante ter um bom relacionamento com meu gestor(a) } \\
\text { e com os demais funcionários da empresa. }\end{array}$ & $98 \%$ & $2 \%$ \\
\hline
\end{tabular}

Fonte: Próprio Autor (2015)

Considerando o relacionamento interpessoal dentro da empresa, 98\% dos respondentes consideram importante ter um bom relacionamento com seus gestores e com os demais funcionários da empresa. Oliveira (2010) afirma que se há uma relação boa entre a Geração $Y$ e seus gestores, ela estabelece uma ligação mais profunda e busca maior desempenho. 
Quanto ao tema qualidade de vida no trabalho, representado na tabela $17,88 \%$ dos respondentes relataram ficar satisfeitos quando a empresa promove ações de saúde e lazer, 90\% consideram importante o respeito à carga horária de trabalho estabelecida, bem como o fornecimento de condições de trabalho adequadas, visto que $100 \%$ consideram importante ter materiais e ferramentas adequadas para desenvolverem seus trabalhos de forma segura. $97 \%$ consideram importante ter estabilidade e equilíbrio entre vida pessoal e profissional, como férias e carga horária flexível.

Os altos índices de aceitação das afirmações sobre qualidade de vida no trabalho podem ser explicados pela nova ética dos profissionais da Geração $Y$ apresentada por Lipkin e Perrymore (2010). Segundo as autoras, os jovens dessa geração se preocupam com a qualidade de vida, com o horário de trabalho e com a integração entre vida pessoal e profissional ao colocaram suas vidas em primeiro lugar ao invés do trabalho, pois, para eles, o trabalho não é a vida, somente faz parte dela.

Tabela 17: Respostas das afirmações sobre qualidade de vida no trabalho

\begin{tabular}{|l|c|c|}
\hline \multicolumn{1}{|c|}{ Pergunta } & $\begin{array}{c}\% \\
\text { Positivas }\end{array}$ & $\begin{array}{c}\% \\
\text { Negativas }\end{array}$ \\
\hline $\begin{array}{l}\text { Fico satisfeito quando a empresa em que trabalho/faço estágio } \\
\text { promove ações de saúde e lazer. }\end{array}$ & $88 \%$ & $12 \%$ \\
\hline $\begin{array}{l}\text { Considero importante a empresa respeitar a carga horária de trabalho } \\
\text { estabelecida e fornecer condições adequadas de trabalho. }\end{array}$ & $90 \%$ & $10 \%$ \\
\hline $\begin{array}{l}\text { Considero importante ter materiais e ferramentas adequadas para } \\
\text { desenvolver o meu trabalho de forma segura. }\end{array}$ & $100 \%$ & $0 \%$ \\
\hline $\begin{array}{l}\text { Considero importante ter estabilidade e equilíbrio entre vida pessoal e } \\
\text { profissional, como férias e carga horária flexível. }\end{array}$ & $97 \%$ & $3 \%$ \\
\hline
\end{tabular}

Fonte: Próprio Autor (2015)

Uma vez que as perguntas desse estudo foram baseadas em práticas de Gestão de Pessoas valorizadas pelos integrantes da Geração Y, tal qual identificado em pesquisa bibliográfica anterior, buscou-se, na última pergunta, pedir que os respondentes ordenassem as práticas por ordem de importância. Assim sendo, foi solicitado que ordenassem de 1 a 4 (1 para o mais importante e 4 para o menos importante) as frases sobre as quatro práticas de Gestão de Pessoas abordadas neste estudo, considerando suas experiências de trabalho e/ou estágio em ambientes organizacionais.

Segundo é afirmado por Oliveira (2010) e conforme foi observado nas respostas apresentadas anteriormente na tabela 12, a Geração Y quer adquirir novos conhecimentos e considera importante ter treinamentos e se desenvolver 
no ambiente organizacional. Porém, ao reunir as práticas de Gestão de Pessoas abordadas nesse estudo, os processos de aprendizagem na posição atual do cargo (curto prazo) e para ocupar posições futuras (longo prazo) apresentados por Gil (2001), apesar de importantes, são considerados os menos importantes para os respondentes que as demais práticas.

Tabela 18: Práticas de Gestão de Pessoas em ordem de importância

\begin{tabular}{|l|c|c|c|c|}
\multicolumn{1}{|c|}{ Resposta } & 10 & 20 & 30 & $4^{\circ}$ \\
\hline $\begin{array}{l}\text { Aprendizagem na posição atual do cargo ou para posições } \\
\text { futuras }\end{array}$ & $13 \%$ & $22 \%$ & $20 \%$ & $45 \%$ \\
\hline Oportunidade de crescimento (carreira) & $47 \%$ & $23 \%$ & $22 \%$ & $8 \%$ \\
\hline Ambiente de trabalho agradável & $13 \%$ & $38 \%$ & $30 \%$ & $18 \%$ \\
\hline Equilibrio entre vida pessoal e profissional & $27 \%$ & $17 \%$ & $28 \%$ & $28 \%$ \\
\hline
\end{tabular}

Fonte: Próprio Autor (2015)

Também é possível observar na tabela 18 que $47 \%$ dos respondentes classificaram o crescimento profissional, ou seja, a carreira, que define a trajetória profissional de uma pessoa, segundo Martins (2010), como a prática de Gestão de Pessoas mais importante para eles, considerando suas experiências no ambiente organizacional. Isso pode ser explicado por uma das características dos jovens da Geração Y apresentada por Santos (2011) e observada nas respostas desse estudo, que é o desejo de fazer carreira de forma rápida, o que faz essa geração ser mais disposta a sair de uma empresa que não possa crescer e se desenvolver.

Em relação às demais práticas de Gestão de Pessoas abordadas nesse estudo, 38\% dos respondentes classificaram como importante a qualidade do ambiente de trabalho e $28 \%$ classificaram que ter equilíbrio entre vida pessoal e profissional é importante no ambiente organizacional. Para Santos (2011), os jovens da Geração Y estão em busca desse equilíbrio, assim como anseiam por qualidade de vida e desejam um ambiente de trabalho agradável (SÁ, LEMOS E CAVAZOTTE, 2014), como pode ser observado.

Dessa forma, a tabela 18 complementa as tabelas anteriores, pois, de acordo com todas as características da Geração Y apresentadas nesse estudo, essa geração valoriza todas as práticas de Gestão de Pessoas abordadas. 


\section{Conclusões e recomendações para novos estudos}

\subsection{Conclusão}

O presente estudo teve como objetivo identificar as práticas de Gestão de Pessoas mais valorizadas pela Geração $Y$ e, para alcançá-lo, foram realizadas pesquisas bibliográficas e de campo. Para a coleta de dados foi elaborado um questionário e a amostra foi composta por 60 alunos formandos do final de 2015 e do meio de 2016 do curso de Administração da PUC-Rio, que integram a Geração Y.

As respostas obtidas nesse estudo possibilitaram afirmar que todas as práticas de Gestão de Pessoas abordadas no referencial teórico foram consideradas importantes para a Geração $\mathrm{Y}$, conforme é apresentado na tabela 19.

Tabela 19: Respostas positivas e negativas do Bloco II do questionário

\begin{tabular}{|c|c|c|c|}
\hline \multicolumn{2}{|c|}{ Práticas de Gestão de Pessoas } & $\%$ Positivas & $\%$ Negativas \\
\hline \multicolumn{2}{|c|}{ Treinamento e Desenvolvimento } & $98 \%$ & $2 \%$ \\
\hline \multirow{3}{*}{ Carreiras } & Carreiras Organizacionais & $54 \%$ & $46 \%$ \\
\cline { 2 - 4 } & Carreiras Sem Fronteiras & $78 \%$ & $22 \%$ \\
\cline { 2 - 4 } & Carreiras Proteanas & $96 \%$ & $4 \%$ \\
\hline \multicolumn{2}{|c|}{ Clima Organizacional } & $99 \%$ & $1 \%$ \\
\hline \multicolumn{2}{|c|}{ Qualidade de Vida no Trabalho } & $94 \%$ & $6 \%$ \\
\hline
\end{tabular}

Fonte: Próprio Autor (2015)

Todas as práticas tiveram altos percentuais de respostas positivas pelos respondentes e, de acordo com elas, treinamento e desenvolvimento são considerados importantes para a Geração $Y$ porque ela é movida por novos desafios que proporcionem adquirir novos conhecimentos, crescimento e desenvolvimento profissional, e caso não encontrem isso em uma organização, estão dispostos a buscarem fora dela (OLIVEIRA, 2010), pois isso está atrelado à vontade dos jovens dessa geração de fazerem carreira com rapidez 
(SÁ,LEMOS E CAVAZOTTE, 2014). Juntamente com o anseio por crescer, é possível perceber que a Geração $Y$ também considera importante ter equilíbrio entre vida pessoal e profissional, além de ter um clima de trabalho agradável (SANTOS, 2011; SÁ, LEMOS E CAVAZOTTE, 2014). De acordo com a pesquisa, essa geração valoriza o ambiente de trabalho, considera importante se desenvolver nele, assim como considera importante receber avaliações de suas ações e o bom relacionamento com o gestor é fundamental para ela (OLIVEIRA, 2010).

No último bloco de perguntas do questionário, foi solicitado aos respondentes que ordenassem, em grau de importância, as quatro práticas de Gestão de Pessoas abordadas nesse estudo e o resultado encontra-se na tabela 20.

Tabela 20: Práticas de Gestão de Pessoas em ordem de classificação

\begin{tabular}{|c|l|}
\hline Ordem & \multicolumn{1}{|c|}{ Práticas de Gestão de Pessoas } \\
\hline $1^{\underline{a}}$ & Oportunidade de crescimento (carreira) \\
\hline $2^{\underline{a}}$ & Ambiente de trabalho agradável \\
\hline $3^{\underline{a}}$ & Equilíbrio entre vida pessoal e profissional \\
\hline $4^{\underline{a}}$ & Aprendizagem na posição atual do cargo ou para posições futuras \\
\hline
\end{tabular}
Fonte: Próprio autor (2015)

Analisando essa questão e outras do questionário, é possível concluir que a oportunidade de crescimento (carreira) constitui a prática de Gestão de Pessoas mais valorizada pela Geração $Y$, pois ela possui a necessidade de crescimento rápido já observada e buscam oportunidades que possibilitem alcançar seu objetivo (OLIVEIRA, 2010). De acordo com as respostas do questionário, essas oportunidades podem estar fora ou dentro da empresa, sendo possível afirmar que as carreiras organizacionais não são o tipo de carreira da Geração Y, pois, conforme Dutra (2010) afirma, atualmente as pessoas estão usando cada vez menos as empresas como referências de suas carreiras, ou seja, cabe a cada um a responsabilidade pela condução de seu crescimento profissional. Isso também é evidenciado pelas respostas relacionadas ao tempo de permanência em seus trabalhos, pois, as respostas aqui encontradas, reforçam a informação que a Geração $Y$ não fica mais de dois anos no mesmo cargo (excluindo-se aqueles que tiveram seus contratos de estágio finalizados no período de dois anos), ao contrário da Geração $X$ (MÓSCA, CEREJA E BASTOS, 2014).

Os jovens $Y$ não são tradicionais como seus pais que possuíam projetos de vida de longo prazo (OLIVEIRA, 2010), mas também não são tão 
independentes como os adeptos das carreiras sem fronteiras que preferem trabalhar com seus próprios planejamentos, muitas das vezes de forma autônoma (DUTRA, 2010). Dessa forma, é possível concluir que esses jovens possuem características relacionadas ao tipo de carreira proteana, pois, de acordo com as respostas do questionário, são mais favoráveis a desenvolverem suas competências e habilidades para atingirem seus objetivos de carreira e de vida, assim como estão em busca de carreiras baseadas em seus valores pessoais, como é proposto por Martins (2010) ao descrever esse tipo de carreira.

Assim, de acordo com esse estudo, é possível observar um fato interessante: ao ordenarem as práticas de Gestão de Pessoas por grau de importância, os respondentes optaram por crescimento profissional, que constitui uma característica muito forte dessa geração. Porém, ao serem expostos às práticas de forma ampla, eles tenderam a considerar todas importantes, o que faz sentido visto que têm significativa relação com diversas características dos jovens da Geração Y, conforme foi apresentado na parte teórica do estudo.

O estudo indica que vale a pena que a área de Gestão de Pessoas tenha uma atenção especial a essas práticas caso queiram atrair e reter os profissionais dessa geração. A Geração $Y$ é exigente e não se preocupa em sair de uma empresa se ela não se adequar aos seus objetivos de vida. Por isso, é preciso que as organizações estejam atentas a esse perfil de jovens que estão chegando ao ambiente empresarial com muita vontade de crescer e fazer carreira (na empresa ou fora dela).

\subsection{Sugestões e recomendações para novos estudos}

O presente estudo trouxe contribuições para o entendimento dessa nova geração de jovens, como ela se comporta no ambiente organizacional e como percebe algumas das práticas tradicionalmente desenvolvidas pela área de Gestão de Pessoas.

Porém, como esse estudo foi realizado com uma amostra por conveniência composta de alunos do curso de Administração da PUC-Rio, é possível que os dados não representem de forma significativa a Geração $Y$ como um todo devido ao tamanho da amostra e também por considerar somente uma faculdade. Sugere-se que a pesquisa seja aplicada para outros cursos de outras faculdades com uma amostra maior para comparar os resultados obtidos com o presente estudo. 
Recomenda-se também que seja incluída uma pergunta para identificar o segmento onde os respondentes trabalham/fazem estágio para que seja analisado, posteriormente, se os tipos de segmentos impactam nas respostas como, por exemplo, se o segmento influencia no equilíbrio entre vida pessoal e profissional.

Outra sugestão é a realização de entrevistas com os membros dessa geração para entender, de forma mais aprofundada, como eles se comportam no ambiente organizacional. Também é válido traçar o perfil dessa geração considerando as classes sociais das quais fazem parte, para entender se este item interfere nas práticas de Gestão de Pessoas valorizadas.

Além disso, recomenda-se entrevistar profissionais de Gestão de Pessoas para verificar o que eles identificam nos jovens da Geração $Y$ e quais práticas estão usando para atender e reter essa geração. 


\section{Referências Bibliográficas}

ALBUQUERQUE, L. G.; FRANÇA, A. C. L. Estratégias de recursos humanos e gestão da qualidade de vida no trabalho: o stress e a expansão do conceito de qualidade total. Revista de Administração, v.33, n.2, p.40-45, 1998.

CHIAVENATO, I. Gestão de pessoas: o novo papel dos recursos humanos nas organizações. 3. ed. Rio de Janeiro: Elsevier, 2010.

DUTRA, J. S. Gestão de carreiras na empresa contemporânea. São Paulo: Atlas, 2010.

FERREIRA, P. I. Clima organizacional e qualidade de vida no trabalho. Rio de Janeiro: LTC, 2013.

GIL, A. C. Gestão de pessoas: enfoque nos papéis profissionais. São Paulo: Atlas, 2001.

2008.

Métodos e técnicas de pesquisa social. 6. ed. São Paulo: Atlas,

KULLOCK, E. Por que as gerações estão no nosso foco? Disponível em: $<$ http://www.focoemgeracoes.com.br/index.php/por-que-as-geracoes-estao-nonosso-foco/> Acesso em: 19 de setembro de 2015.

LIPKIN, N.; PERRYMORE, A. A geração y no trabalho: como lidar com a força de trabalho que influenciará definitivamente a cultura da sua empresa. Rio de Janeiro: Elsevier, 2010.

LUZ, R. Gestão do clima organizacional. Rio de Janeiro: Qualitymark, 2003.

MARTINS, H. T. Gestão de Carreiras na Era do Conhecimento: abordagem conceitual \& resultados de pesquisa. 2. ed. Rio de Janeiro: Qualitymark, 2010.

MÓSCA, H. M. B.; CEREJA, J. R.; BASTOS, S. A. P. Gestão de Pessoas nas organizações contemporâneas. 1. ed. Rio de Janeiro: LTC, 2014.

OLIVEIRA, S. Geração Y: o nascimento de uma nova versão de líderes. São Paulo: Integrare Editora, 2010.

SANTOS, A. L. A geração $\mathbf{Y}$ nas organizações complexas: um estudo exploratório sobre a gestão dos jovens nas empresas. São Paulo, 2011. 150 p. Dissertação (Mestrado em Administração) - Departamento de Administração: 
Universidade de São Paulo.

SÁ, P. F.; LEMOS, A. H. C.; CAVAZOTTE, F. S. C. N. Expectativas de carreira na contemporaneidade: o que querem os jovens profissionais? Revista ADM.MADE, v.18, n.2, p.8-27, 2014.

VELOSO, E. F. R.; DUTRA, J. S.; NAKATA, L. E. Percepção sobre carreiras inteligentes: diferenças entre as gerações $\mathrm{Y}, \mathrm{X}$ e baby boomers. Associação Nacional de de Pós-Graduação e Pesquisa em Administração, 2008.

VERGARA, S. C. Gestão de pessoas. São Paulo: Atlas, 1999.

Projetos e Relatórios de Pesquisa em Administração. 5. ed. São Paulo: Atlas, 2004. 


\section{Apêndice 1}

Olá!

Meu nome é Manuela e sou aluna de Administração da PUC-Rio.

Preciso de sua ajuda para responder esta pesquisa sobre práticas de Gestão de Pessoas e Geração $Y$ para o meu trabalho de conclusão de curso. Ela é destinada apenas aos alunos de Administração da PUC-Rio que são formandos de 2015.2 ou 2016.1 e que tenham alguma experiência como trabalho ou estágio.

É simples e rápida de responder.

Muito obrigada!

\section{PARTE I}

1 - Você é estudante de Administração da PUCRio?

- Sim

○ Não

2 - Você se formará no final de 2015 ou no meio de 2016 ?

- Sim, no final de 2015

- Sim, no meio de 2016

- Não

3 - Já trabalhou ou já fez estágio?

- Sim, já trabalhei

- Sim, já fiz estágio

- Sim, já trabalhei e fiz estágio

○ Não

4 - Qual o tipo de empresa?

- Privada

- Pública

- ONG (Organizações Não Governamentais)

- Outros:

5 - Trabalha ou faz estágio atualmente?

- Sim, trabalho

- Sim, faço estágio

- Não 
6 - Por qual(is) motivo(s) você saiu da empresa? (Pode escolher mais de um item)
- Sem oportunidade de crescimento
- Horário de trabalho não respeitado
- Dificuldade de equilibrar vida pessoal e profissional
- Relacionamento ruim com o gestor
- Não havia reconhecimento por suas ações
- Baixa remuneração
- Queria assumir novos desafios
- Outros:

7 - Por qual(is) motivo(s) você sairia de sua atual empresa? (Pode escolher mais de um item)
- Sem oportunidade de crescimento
- Horário de trabalho não respeitado
- Dificuldade de equilibrar vida pessoal e profissional
- Relacionamento ruim com o gestor
- Não há reconhecimento por suas ações
- Baixa remuneração
- Quer assumir novos desafios
- Outros:

8 - Está ou esteve por quanto tempo em seu último trabalho ou estágio?
- 0 a 5 meses
- 6 a 11 meses
- 1 a 2 anos
- Acima de 3 anos

9 - Você consegue equilibrar sua vida pessoal e profissional?
- Sim
○ Não

10- Você busca equilibrar sua vida pessoal e profissional?
- Sim
○ Não

11 - Gênero?

○ Feminino

- Masculino

12- Idade?
○ $18-23$
- 24-29
- 30-35 


\section{PARTE II}

Marque se você concorda totalmente, concorda parcialmente, discorda parcialmente ou discorda totalmente das afirmações abaixo:

\begin{tabular}{|c|c|c|c|c|}
\hline & $\begin{array}{c}\text { Concordo } \\
\text { totalmente }\end{array}$ & $\begin{array}{c}\text { Concordo } \\
\text { parcialmente }\end{array}$ & $\begin{array}{c}\text { Discordo } \\
\text { parcialmente }\end{array}$ & $\begin{array}{l}\text { Discordo } \\
\text { totalmente }\end{array}$ \\
\hline \multicolumn{5}{|l|}{$\begin{array}{l}\text { Considero importante a possibilidade de ter treinamentos e me } \\
\text { desenvolver no ambiente organizacional. }\end{array}$} \\
\hline \multicolumn{5}{|l|}{$\begin{array}{l}\text { Acredito que os treinamentos oferecidos pela empresa aumentam meu } \\
\text { desempenho nas atividades profissionais. }\end{array}$} \\
\hline \multicolumn{5}{|l|}{$\begin{array}{l}\text { Busco empresas que usam mecanismos para reconhecer e valorizar } \\
\text { seus funcionários. }\end{array}$} \\
\hline \multicolumn{5}{|l|}{$\begin{array}{l}\text { Considero importante crescer juntamente com a empresa, } \\
\text { desenvolvendo-me constantemente. }\end{array}$} \\
\hline \multicolumn{5}{|l|}{ Prefiro me desenvolver dentro da organização do que fora dela. } \\
\hline \multicolumn{5}{|l|}{$\begin{array}{l}\text { Pretendo construir carreira na empresa em que trabalho/faço estágio, } \\
\text { ou que viso trabalhar, e chegar ao topo da hierarquia. }\end{array}$} \\
\hline \multicolumn{5}{|l|}{$\begin{array}{l}\text { Prefiro estabilidade (ficar na empresa um longo período) e segurança } \\
\text { do que liberdade e autonomia. }\end{array}$} \\
\hline \multicolumn{5}{|l|}{$\begin{array}{l}\text { Prefiro interagir com pessoas e empresas além das fronteiras da } \\
\text { minha organização. }\end{array}$} \\
\hline \multicolumn{5}{|l|}{$\begin{array}{l}\text { Prefiro sair da empresa em que estou se não houver oportunidades de } \\
\text { desenvolvimento constantes. }\end{array}$} \\
\hline \multicolumn{5}{|l|}{$\begin{array}{l}\text { Prefiro trabalhar com meu próprio planejamento a trabalhar dentro de } \\
\text { uma empresa. }\end{array}$} \\
\hline \multicolumn{5}{|l|}{$\begin{array}{l}\text { Utilizo sempre minhas competências e habilidades para atingir meus } \\
\text { objetivos de carreira e de vida. }\end{array}$} \\
\hline \multicolumn{5}{|l|}{$\begin{array}{l}\text { Busco oportunidades de carreiras baseadas em meus valores } \\
\text { pessoais, dentro ou fora da empresa. }\end{array}$} \\
\hline \multicolumn{5}{|l|}{$\begin{array}{l}\text { Prefiro sair da empresa em que estou se o meu cargo ná se } \\
\text { aproximar das minhas necessidades pessoais de carreira e de } \\
\text { sucesso. }\end{array}$} \\
\hline \multicolumn{5}{|l|}{$\begin{array}{l}\text { Prefiro um ambiente agradável para desenvolver minhas atividades } \\
\text { profissionais. }\end{array}$} \\
\hline \multicolumn{5}{|l|}{$\begin{array}{l}\text { Acredito que um bom clima organizacional impacta no meu } \\
\text { desempenho e nos resultados da empresa. }\end{array}$} \\
\hline \multicolumn{5}{|l|}{$\begin{array}{l}\text { Sinto-me mais motivado(a) e satisfeito(a) com um bom clima de } \\
\text { trabalho. }\end{array}$} \\
\hline \multicolumn{5}{|l|}{$\begin{array}{l}\text { Considero importante receber feedbacks constantemente sobre } \\
\text { minhas atividades. }\end{array}$} \\
\hline \multicolumn{5}{|l|}{$\begin{array}{l}\text { Considero importante ter um bom relacionamento com meu gestor(a) e } \\
\text { com os demais funcionários da empresa. }\end{array}$} \\
\hline \multicolumn{5}{|l|}{$\begin{array}{l}\text { Fico satisfeito quando a empresa em que trabalho/faço estágio } \\
\text { promove ações de saúde e lazer. }\end{array}$} \\
\hline \multicolumn{5}{|l|}{$\begin{array}{l}\text { Considero importante a empresa respeitar a carga horária de trabalho } \\
\text { estabelecida e fornecer condições adequadas de trabalho. }\end{array}$} \\
\hline \multicolumn{5}{|l|}{$\begin{array}{l}\text { Considero importante ter materiais e ferramentas adequadas para } \\
\text { desenvolver o meu trabalho de forma segura. }\end{array}$} \\
\hline $\begin{array}{l}\text { Considero importante ter estabilidade e equilíbrio entre vida pessoal e } \\
\text { profissional, como férias e carga horária flexível. }\end{array}$ & & & & \\
\hline
\end{tabular}




\section{PARTE III}

Ordene em grau de importância os itens abaixo, considerando sua(s) experiência(s) em um ambiente organizacional (1 é o mais importante e 4 é o menos importante para você):

Aprendizagem na posição atual do cargo ou para posições futuras

_ Oportunidade de crescimento (carreira)

_ Ambiente de trabalho agradável

__ Equilíbrio entre vida pessoal e profissional 